\title{
Plant, soil and faunal responses to a contrived $\mathrm{pH}$ gradient
}

\author{
Sarah Duddigan • Tandra Fraser • Iain Green • Anita \\ Diaz • Tom Sizmur • Mark Tibbett $\mathbb{D}$
}

Received: 7 December 2020 / Accepted: 3 February 2021 / Published online: 21 February 2021

(C) The Author(s) 2021

\begin{abstract}
Purpose To build a more holistic understanding of soil $\mathrm{pH}$ change we assessed the synchronised effects of a contrived soil $\mathrm{pH}$ change on soil chemistry, vegetation growth and nutrition, and soil faunal abundance and diversity.

Methods We established a fifteen year old field experiment with a contrived $\mathrm{pH}$ gradient ( $\mathrm{pH} 4.3$ to 6.3 ) and measured the effect on soil chemistry, plant biomass and elemental composition and the impact of these changes on soil fauna (earthworms, nematodes, rotifers and tardigrades) and biological indices (based on ecological group structures of earthworms and nematodes). A single $20 \times 20 \times 20 \mathrm{~cm}$ soil block was excavated from each sample site to directly attribute biotic parameters in the block to the abiotic (soil) conditions.

Results Acidification affected the extractable concentrations of $\mathrm{Al}, \mathrm{Ca}, \mathrm{Mn}$ and $\mathrm{P}$ and the $\mathrm{C}: \mathrm{N}$ ratio of the soil
\end{abstract}

Responsible Editor: Jeffrey Walck.

S. Duddigan $\cdot$ T. Fraser $\cdot$ M. Tibbett $(\bowtie)$

Department of Sustainable Land Management \& Soil Research

Centre, School of Agriculture, Policy and Development,

University of Reading, Reading, Berkshire, UK

e-mail: m.tibbett@ reading.ac.uk

I. Green · A. Diaz

Department of Life \& Environmental Sciences, Bournemouth

University, Poole, Dorset, UK

T. Sizmur

Department of Geography and Environmental Science, University of Reading, Reading, Berkshire, UK and caused a reduction in plant $\mathrm{Ca}\left(\mathrm{r}_{\mathrm{s}}\right.$ for $\mathrm{pH}$ vs $\mathrm{Ca}=$ $0.804 p<0.01)$, an increase in plant $\mathrm{Mn}\left(\mathrm{r}_{\mathrm{s}}=-0.450 p=\right.$ 0.019 ), along with significant decrease in root:shoot ratio $\left(\mathrm{r}_{\mathrm{s}}=0.638, p<0.01\right)$. There was a significant positive correlation between $\mathrm{pH}$ and earthworm index $\left(\mathrm{r}_{\mathrm{s}}=0.606, p<0.01\right)$, and a negative correlation between $\mathrm{pH}$ and nematode index $\left(\mathrm{r}_{\mathrm{s}}=-0.515, p<0.01\right)$. Conclusion Soil pH influenced the mobility of $\mathrm{Ca}, \mathrm{Al}$, $\mathrm{Mn}$ and $\mathrm{P}$, which in turn has impacted on plant tissue chemistry and plant biomass ratios. Linked changes in soil chemistry and vegetation had a corresponding effect on the abundance and diversity of nematodes and earthworms in the soil blocks.

Keywords Soil acidification $\cdot$ Sulphur $\cdot$ Sulfur $\cdot$ Soil biology . Soil biodiversity . Soil biological indices . Earthworms · Nematodes · Grassland · Pasture · Heathland

\section{Introduction}

Soil acidification is a major global problem (Sullivan and Gadd 2019), which contributes to the widespread degradation of soils. A number of natural and anthropogenic processes lead to decreased soil $\mathrm{pH}$, including the mineralisation of organic matter, natural precipitation, nutrient uptake by plants, excretion of organic acids by plants roots and fungi, deposition of acid gases (e.g. acid rain) and the use of acidifying fertilisers, particularly those containing sulphur (S), ammonium and urea (Gadd 1999; Goulding 2016; Rowell and Wild 1984). 
Ironically, as deposition of sulphuric gases has decreased due to emission controls, the use of S fertilisers has increased to prevent $\mathrm{S}$ deficiency in crops (DEFRA 2019). Ecosystems differ in response to acidifying substances with grasslands being among the most sensitive to change (Tian and Niu 2015) and therefore most likely to be responsive to changes in edaphic conditions.

Biological parameters, such as soil organism abundance and diversity, have long been recognised as potentially useful indicators of soil quality (Doran and Zeiss 2000; Ritz et al. 2009). This is largely due to the sensitivity of organisms such as nematodes and earthworms to soil disturbance (Falco et al. 2015). Soil abiotic conditions, including $\mathrm{pH}$, have been reported to impact soil biodiversity and organism distribution (Bardgett and Van Der Putten 2014; Griffiths et al. 2011; Tibbett et al. 2020). Manipulation of soil $\mathrm{pH}$ in both arable and grassland systems through liming, for example, has been shown to increase the abundance of bacteria, nematodes and earthworms, and reduce fungal abundance (Holland et al. 2018). Subsequent work, however, suggests that liming had a limited effect on soil microbial and nematode community structure (Neilson et al. 2020) and soil pH is negatively correlated with nematode abundance (van den Hoogen et al. 2019). Soil $\mathrm{pH}$ can affect the abundance and diversity of soil organisms through a range of mechanisms: (i) A direct effect on their survival and growth. Some bacterial taxa, for example, have growth tolerances within a narrow $\mathrm{pH}$ range. This small niche can lead to competitive exclusion if $\mathrm{pH}$ lies beyond the optimum range i.e. broad $\mathrm{pH}$ niche bacteria outcompete those with narrow ranges (Rousk et al. 2010); (ii) The modification of their metabolism (Hartman and Richardson 2013), including the activity of microbial enzymes (Neina 2019; Turbé et al. 2010); (iii) The alteration of the bioavailability of both nutrients and contaminants (Turbé et al. 2010). Soil pH affects a number of processes that will influence the solubility, mobility and bioavailability of elements through mineralisation of organic bound elements, chemical adsorption and precipitation reactions (Holland et al. 2018; Neina 2019). An increase in soil $\mathrm{pH}$ through liming, for example, can enhance the availability of key nutrients such as $\mathrm{N}$ and $\mathrm{P}$, and reduce the availability of elements that can be toxic to microbial growth such as $\mathrm{Al}, \mathrm{Cu}, \mathrm{Fe}$ and $\mathrm{Mn}$ (Holland et al. 2018). Finally there are (iv) indirect effects on primary producers and lower trophic organisms. The mechanisms above can affect abundances and diversity of plant communities and microorganisms. Therefore, higher trophic organisms that feed on these will be secondarily affected by the change in resource availability and quality (including elemental composition). Soil $\mathrm{pH}$, and its resultant biogeochemical effects, is commonly considered in relation to microbial communities, with relatively little consideration given to soil fauna by comparison.

Soil organisms live in a heterogeneous ecosystem where small spatial scales are associated with biological trends that are spatially unpredictable (Nielsen et al. 2010), and where random point auger sampling may often neglect key species and hence field-scale experimental responses. Therefore, in order to sample a representative portion of the faunal and plant habitat we excavated soil blocks from a long-term field experiment with a contrived $\mathrm{pH}$ gradient. Single $20 \times 20 \times 20 \mathrm{~cm}$ blocks were retrieved from each of the sampling sites, fifteen years after application of acidifying agents, and all analysis is conducted on the sample soil block. We assessed how soil acidification influenced soil chemistry in the block, and how this affected plants and particularly soil faunal responses. The abundance data obtained, therefore, can be directly attributed to the abiotic conditions in which those organisms were found. By using a contrived $\mathrm{pH}$ gradient using amendments, on a single soil type, rather than comparing multiple sites across a naturally occurring $\mathrm{pH}$ gradient, we limit the confounding effects of edaphic and environmental changes across landscapes (i.e. soil texture, rainfall etc.) driving changes in the soil biology.

We hypothesised that: (i) Soil chemistry would be substantially altered by sulphurous acidifying treatments and that changes would be seen across the $\mathrm{pH}$ gradient; (ii) Plant biomass and elemental composition would be significantly different between treatments and across the $\mathrm{pH}$ gradient and (iii) Soil fauna abundance (earthworms, nematodes, rotifers and tardigrades) and biological indices (based on earthworm and nematode ecological group structure), would be negatively affected in acidified soils. We tested these hypotheses using a contrived $\mathrm{pH}$ gradient of experimental field plots using sulphurous amendments (elemental sulphur and ferrous sulphate) as acidifying treatments on circumneutral grassland soil. The subsequent $\mathrm{pH}$ gradient was used to examine the effect of $\mathrm{pH}$ on abundance and biological indices based on the nematode and earthworm functional group structure. These two invertebrate groups have been previously identified as potential indicators of soil health (Stork and Eggleton 1992). 


\section{Materials and methods}

Site description and approach

Thirty $50 \times 50 \mathrm{~m}$ experimental plots were established in 1999 as part of a heathland restoration experiment, on the Isle of Purbeck, UK $\left(50.658754^{\circ} \mathrm{N},-2.066839^{\circ} \mathrm{W}\right)$. The plots were established on agricultural pasture, created during the 1950s and 1960s through application of rock phosphate, manure and chalk marl for agricultural improvement of the podzolic soil of the native heathland. This application increased the $\mathrm{pH}$ and soil nutrients to support the growth of grassland for grazing. Across this improved pasture, plots were amended with either: (i) elemental sulphur, as Brimstone 90 (90\% S); (ii) ferrous sulphate as Wet Copperas 50 $13 \% \mathrm{~S}$ ); or (iii) left as an unamended control (each replicated 10 times). Treatments were applied in 2000 at a rate of $2000 \mathrm{~kg} \mathrm{ha}^{-1}$, with an additional $1600 \mathrm{~kg} \mathrm{ha}^{-1}$ applied in 2001. See Diaz et al. (2008) and Tibbett et al. (2019) for further details on the experimental design and landscape features.

A single $20 \times 20 \times 20 \mathrm{~cm}$ cube of soil or 'soil block' was excavated from each one of the thirty sampling plots, and all analysis (abiotic and biotic) conducted on each soil block, allowing for ten replicate blocks for each of the three treatments. This way the faunal abundance data obtained from each block can be directly attributed to the abiotic conditions (the habitat) in which those organisms were found (Fig. 1). The position of the block within each plot was random, but at least $2 \mathrm{~m}$ from the plot boundary to account for possible boundary effects.

Soil, plant and earthworm sampling

Soil block samples were collected in November 2016. For each plot, the soil block was removed using a flat shovel and placed in trays in the field for hand sorting. Earthworms were carefully removed, counted and placed in a subsample of the same soil to be transported back to the lab for classification. Specimens were rinsed, blotted dry, individually weighed, recorded as juvenile or adult, and classified as epigeic, endogeic or anecic. Adult earthworms were also identified to species level following Sherlock (2012).

Soil from the block was homogenized prior to collecting subsamples for analysis. Soil samples were sieved to $3.35 \mathrm{~mm}$ and $\sim 100 \mathrm{~g}$ was stored at $4{ }^{\circ} \mathrm{C}$ for nematode extractions. The remainder of the soil was airdried for $5 \mathrm{~d}$, a $10 \mathrm{~g}$ subsample of dry soil was then ground to $\sim 0.2 \mathrm{~mm}$ using a disc mill for $\mathrm{C}$ and $\mathrm{N}$ determination (detailed below) and the remainder retained for $\mathrm{pH}$ and extractable elements analysis (detailed below).

All plant biomass, including roots, were collected in the field from the $20 \times 20 \mathrm{~cm}$ surface area of the soil block. Whilst every effort was made to sample all roots, it was not possible to obtain all fine roots. Shoots and roots were separated, washed with water to remove adhered soil, dried to a constant mass at $60{ }^{\circ} \mathrm{C}$, and dry weights recorded. Shoot samples (all aboveground vegetation) were then ground to $\sim 0.2 \mathrm{~mm}$ using a disc mill and analysed to give a complete plant community chemical composition.

Nematode, rotifer and tardigrade extractions

Nematodes, rotifers and tardigrades were extracted from $\sim 100 \mathrm{~g}$ fresh soil with a modified Baermann funnel technique by substituting extraction trays for funnels, with samples collected after 24 and 72 h. Nematodes, rotifers and tardigrades in the extracts were counted while alive on a Leitz Wilovert inverted microscope at $4 \mathrm{x}$ magnification. The two sampling times were counted separately and then combined. Identification to feeding group level was completed on 100 nematodes per sample as specified by Yeates (2003) and Yeates et al. (1993). Abundance was expressed as the number of individuals per $100 \mathrm{~g}$ soil dry weight equivalent.

Soil analysis

Soil $\mathrm{pH}$ for each soil block was measured as a 2.5:1 water-soil slurry after shaking for $15 \mathrm{~min}$ at $120 \mathrm{rpm}$ (Rowell 1994).

Extraction of Al, $\mathrm{Ca}, \mathrm{Cu}, \mathrm{Fe}, \mathrm{K}, \mathrm{Mg}, \mathrm{Mn}, \mathrm{P}$ and $\mathrm{S}$ was conducted on a subsample of each soil block using a Mehlich III extraction (Mehlich 1984). $2.0 \pm 0.05 \mathrm{~g}$ soil (air dried; <3.35 mm sieved) was weighed into a $50 \mathrm{~mL}$ centrifuge tube with $20.0 \mathrm{~mL}$ of Mehlich III extracting solution. This consisted of $0.2 \mathrm{M} \mathrm{CH}_{3} \mathrm{COOH} ; 0.25 \mathrm{M}$ $\mathrm{NH}_{4} \mathrm{NO}_{3} ; 0.015 \mathrm{M} \mathrm{NH}_{4} \mathrm{~F} ; 0.013 \mathrm{M} \mathrm{HNO}_{3}$; and $0.001 \mathrm{M}$ EDTA adjusted to a $\mathrm{pH}$ of $2.50 \pm 0.05$. Centrifuge tubes were placed on an end-over-end shaker (40 rpm) for $5 \mathrm{~min}$. After shaking, the suspension was filtered immediately through Whatman No. 42 filter paper. Extractions were analysed for the abovementioned elements 


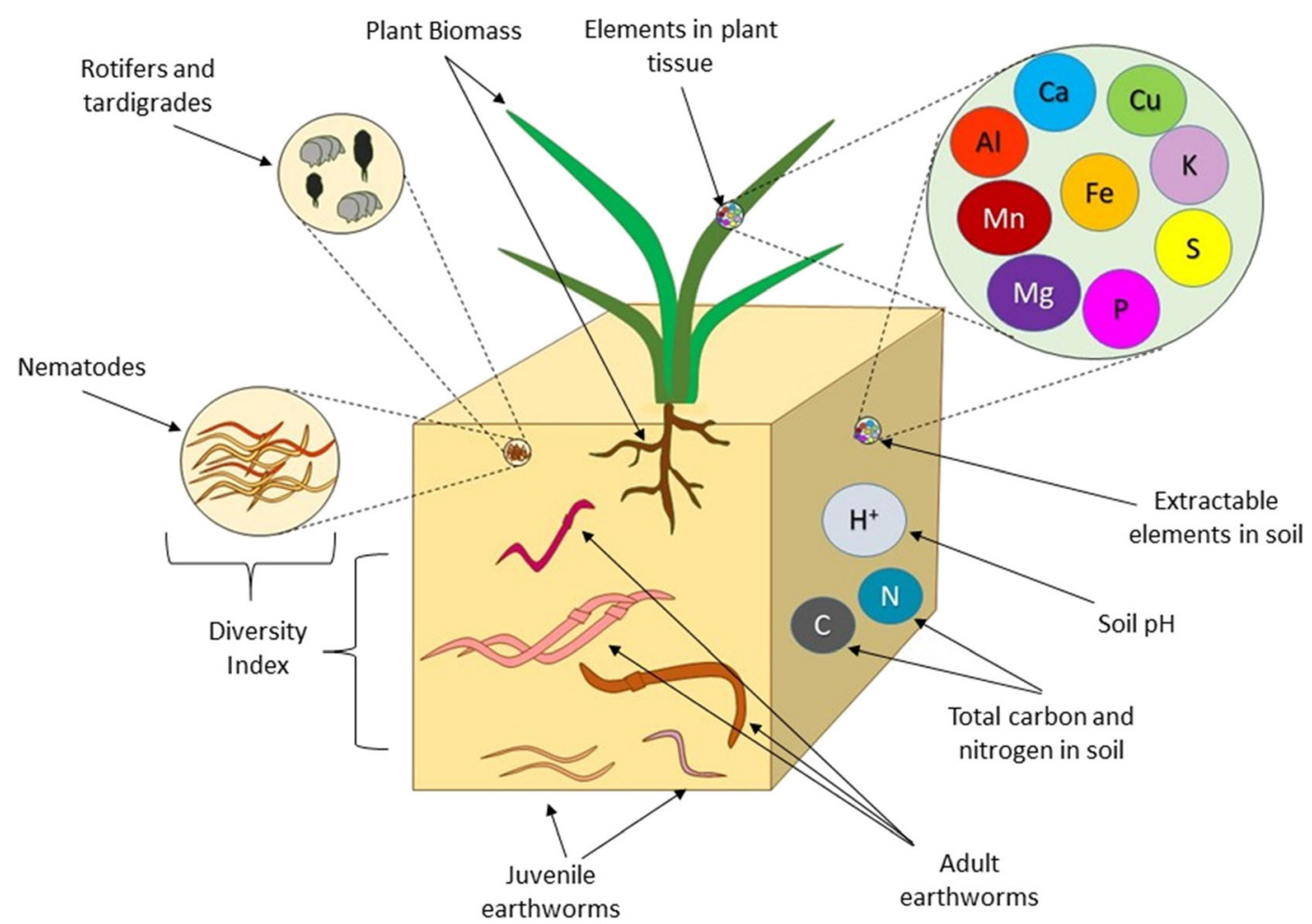

Fig. 1 Schematic of soil block approach and data obtained

using a Perkin Elmer 7300 Dual View inductively coupled plasma - optical emission spectrometer (ICPOES) (Perkin Elmer Inc., Massachusetts, USA). In house (University of Reading - Sonning Series) reference samples were run alongside with a mean $100.9 \% \pm$ 6.4 recovery for the elements analysed.

Total $\mathrm{C}$ and $\mathrm{N}$ content of dried, ground, soil samples from each block were determined using a Thermo Scientific Flash 2000 C/N Analyser (Thermo Fisher Scientific, Massachusetts, USA). Six replicates of an in-house QC material that is traceable to GBW07412 (certified for N by State Bureau of Technical Supervision, The People's Republic of China) and AR-4016 (certified for C by Alpha Resources Inc. with ISO 17025 accreditation) were run alongside samples with recoveries of $100 \% \pm 4$ and $99 \% \pm 12$ for $\mathrm{N}$ and $\mathrm{C}$, respectively.

Plant tissue analysis

Total $\mathrm{Al}, \mathrm{Ca}, \mathrm{Cu}, \mathrm{Fe}, \mathrm{K}, \mathrm{Mg}, \mathrm{Mn}, \mathrm{P}$ and $\mathrm{S}$ in the shoots of the plant community were determined using nitric acid digestion. $0.5 \mathrm{~g}$ of ground, milled, dried, plant material was weighed into a MARSXpress (CEM Microwave Technology Ltd., Buckingham, UK), digestion tube with $2 \mathrm{~mL}$ ultra-pure water and $8 \mathrm{~mL}$ trace element grade concentrated nitric acid. Tubes were left to stand open for $15 \mathrm{~min}$ to predigest before being capped and placed into a MARS 6 microwave digestion system (CEM Microwave Technology Ltd., Buckingham, UK). Tubes were ramped to $200{ }^{\circ} \mathrm{C}$ for $20 \mathrm{~min}$, held at $200{ }^{\circ} \mathrm{C}$ for $10 \mathrm{~min}$, and cooled for $15 \mathrm{~min}$. Digested material was then filtered through Whatman No. 540 filter paper and diluted prior to analysis with Perkin Elmer 7300 Dual View ICP-OES (Perkin Elmer Inc., Massachusetts, USA). Four replicates of IPE 898 Cabbage (Brassica oleracea) were run alongside samples (certified by Wageningen Evaluating Programs for Analytical Laboratories, WEPAL), with an average recovery of $98 \% \pm 11$ for the 9 elements measured.

Soil biological indices

Two biological indices were calculated using the functional groups identified for earthworms and nematodes in each block. An index of trophic diversity (ITD) was calculated for nematodes, as described by (Bianchelli et al. 2013). Calculated as: 


$$
\text { 1-ITD, whereITD }=g_{1}^{2}+g_{2}^{2}+g_{n}^{2}
$$

$g$ is the relative contribution of each trophic group (bacterial feeder, fungal feeder, plant parasite, omnivore and predator) to the total number of individuals, and $n$ is the number of groups. A higher 1-ITD is indicative of greater diversity.

A Soil Biological Quality Index based on earthworms, or QBS-e (Fusaro et al. 2018), was calculated for each soil block using the abundance of adult and juveniles in each ecological group (epigeic, endogeic and anecic) as follows:

$$
\begin{aligned}
\text { QBS-e }= & \left(E M l_{\text {epi,ad }} * \mathrm{~N}\right)+\left(E M l_{\text {epi juv }} * \mathrm{~N}\right) \\
& +\left(E M l_{\text {end }, \text { ad }} * \mathrm{~N}\right)+\left(E M l_{\text {end }, \mathrm{juv}} * \mathrm{~N}\right) \\
& +\left(E M l_{\text {ane }, \mathrm{ad}} * \mathrm{~N}\right)+\left(E M l_{\text {ane }, \mathrm{juv}} * \mathrm{~N}\right)
\end{aligned}
$$

Where $\mathrm{N}$ is the number of individuals per $\mathrm{m}^{2}$ of each ecological group. The EMI is the EcoMorphological score attributed to each ecological category, as assigned and described by Fusaro et al. (2018). Resulting in the following:

$$
\begin{aligned}
\text { QBS-e }= & \left(3 * \mathrm{~N}_{\text {epi,ad }}\right)+\left(2.5 * \mathrm{~N}_{\text {epi,juv }}\right) \\
& +\left(3.2 * \mathrm{~N}_{\text {end }, \text { ad }}\right)+\left(2.5 * \mathrm{~N}_{\text {end,juv }}\right) \\
& +\left(14.4 * \mathrm{~N}_{\text {ane }, \mathrm{ad}}\right)+\left(10 * \mathrm{~N}_{\text {ane,juv }}\right)
\end{aligned}
$$

These EMI scores have been designated to each group according to their ecological role, physiological functions and body mass. For example, larger earthworms contribute more in terms of physical function (such as burrowing), resulting in adult worms having larger scores than juvenile ones. Anecic earthworms have the highest score because of their deep-burrowing and large body size, therefore creating 'optimal' soil conditions. Full details of the designation of these scores can be found in Fusaro et al. (2018).

\section{Statistics}

We have an experiment that allows an analysis by categorical treatment (i.e. sulphurous amendment) but the experiment also provides a unique opportunity to analyse as a $\mathrm{pH}$ gradient. Results presented in the following sections have been explored both as a mean per treatment (tested for equal variance using a Levene's test), and as linear data across the $\mathrm{pH}$ gradient (tested for normality using an Anderson-Darling test). All statistical analyses were conducted using Minitab (Version 18.0, Minitab LLC, Pennsylvania, USA). Significance of treatment effects of sulphurous amendments were determined using Kruskal-Wallis one-way ANOVA on ranks, with Bonferroni post-hoc testing. Significance of correlative relationships was investigated using Spearman's rank order correlation.

Multivariate analysis of soil and plant tissue chemistry was also conducted using PRIMER Version 6.0 (PRIMER-e Quest Research Ltd. Auckland, New Zealand). Using the softwares 'normalise pre-treatment' function, all data were normalised before generating a resemblance matrix of Euclidean distances between samples (Clarke and Gorley 2006). Similarities between treatments were assessed through multidimensional scaling (MDS) and analysis of similarities (ANOSIM). All tests for significance were performed at the $95 \%$ level.

\section{Results}

Soil $\mathrm{pH}$

Application of sulphurous amendments resulted in a $\mathrm{pH}$ gradient across the 30 plots, ranging from 4.28 to 6.27 (Fig. 2). Application of elemental sulphur resulted in significantly lower soil $\mathrm{pH}$ than control plots, but application of ferrous sulphate did not alter $\mathrm{pH}$ significantly from control plots (Fig. 2).

\section{Soil and plant chemistry}

Table 1 outlines soil and plant nutrient concentrations as a function of both sulphurous amendment and $\mathrm{pH}$ gradient. Soil extractable concentrations of $\mathrm{Ca}$ were significantly reduced in the elemental sulphur treatment compared to the control. As with $\mathrm{pH}$, application of ferrous sulphate did not alter extractable concentrations of any of the soil elements measured compared to the control (Table 1). Although a large amount of sulphur was applied to the elemental sulphur and ferrous sulphate treatments, there was no significant difference in $\mathrm{S}$ concentrations in the soil 15 years after the final application. Application of ferrous sulphate resulted in higher levels of Fe than the soils of the elemental sulphur treatment, but did not significantly raise the extractable $\mathrm{Fe}$ concentration compared to the control. Application 
Fig. 2 Soil pH in amended soils. Including individual values for each of the 30 plots $(\bullet)$ and mean $\mathrm{pH}$ of each treatment $(\boldsymbol{\Delta} \mathbf{\nabla})$ with error bars for standard error $(\mathrm{n}=$ 10). Means labelled with the same letter $(a, b)$ indicate treatments that have no significant difference according to Kruskal-Wallis and Bonferroni post-hoc testing $(p>$ 0.05 )

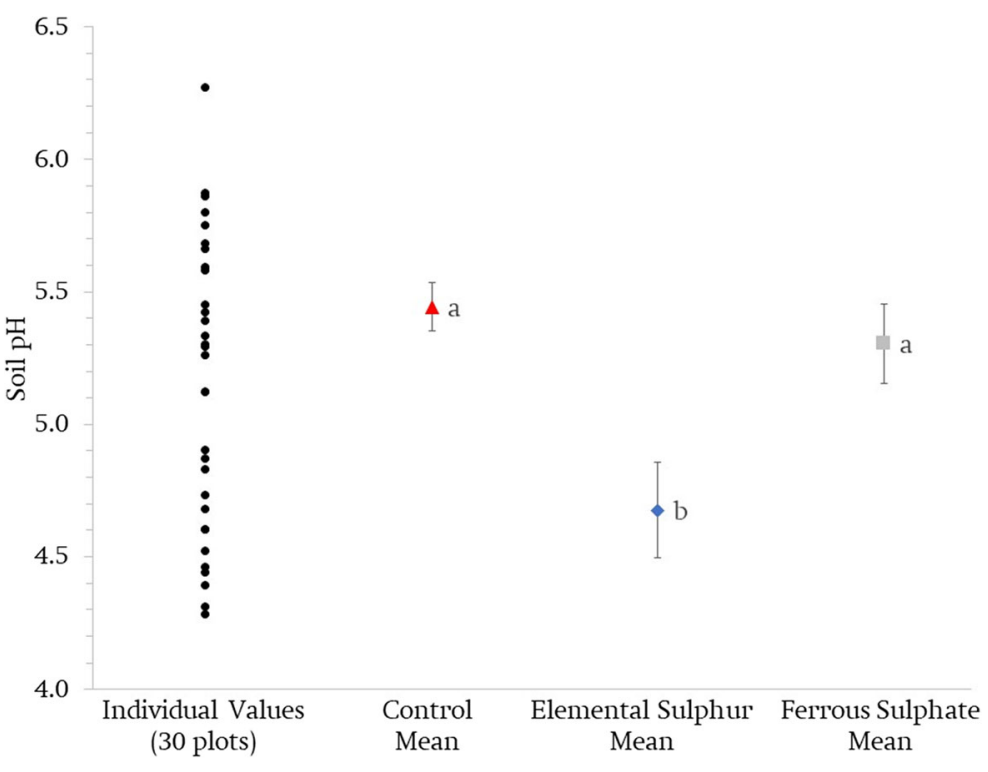

of ferrous sulphate resulted in significantly lower extractable $\mathrm{Cu}$, compared to elemental sulphur, but not to an extent to be significantly lower than the control. There was a significant increase in soil extractable $\mathrm{Ca}$, $\mathrm{Mn}$ and $\mathrm{P}$ as $\mathrm{pH}$ increases along the gradient, and a significant reduction in soil extractable $\mathrm{Al}$ and $\mathrm{C}: \mathrm{N}$ ratio (Table 1).

Only the $\mathrm{Al}$ and $\mathrm{Ca}$ concentration of the plant community shoots were significantly different between treatments (Table 1). Extractable $\mathrm{Al}$ and $\mathrm{Ca}$ was reduced in the elemental sulphur treatment, when compared to the control. The only significant correlations with soil $\mathrm{pH}$ observed in the plant community shoots were found for $\mathrm{Ca}, \mathrm{Mn}$ and $\mathrm{S}$. A significant increase in the plant community shoot $\mathrm{Ca}$ and $\mathrm{S}$ was seen with increasing $\mathrm{pH}$, and a decrease in shoot Mn (Table 1).

ANOSIM of soil chemical parameters show the elemental sulphur treatment was significantly different to the ferrous sulphate and control treatments (Table 2). Ferrous sulphate soil chemistry did not differ from the control. Elemental composition of in the plant community shoot biomass did not show any significant treatment effect (Table 2).

\section{Plant biomass}

Plants growing on plots treated with elemental sulphur had significantly higher shoot biomass than those growing in the ferrous sulphate or the control treated plots
(Fig. 3a). There was a significant decrease in root:shoot ratio with acidification (Fig. 3b).

Fauna abundance

Total, adult and juvenile earthworm abundance was significantly lower in the elemental sulphur treatment compared to the control (Table 3). This effect was not shown between ferrous sulphate and control treatments. Endogeic earthworms were the only functional group that showed a significant treatment effect in abundance between the elemental sulphur and control (Table 3).

There was a significant positive correlation between soil $\mathrm{pH}$ and total, adult, and juvenile earthworm abundance. This change in total earthworm abundance over the $\mathrm{pH}$ gradient appeared to be driven by changes in the endogeic and anecic earthworm population, rather than the epigeic earthworms. Only the total anecic, and total adult and juvenile abundance of endogeic earthworms were significantly correlated to soil $\mathrm{pH}$.

Total earthworm abundance also had significant positive correlations with soil extractable $\mathrm{P}$ and $\mathrm{Ca}$, and plant tissue $\mathrm{Ca}$. There was a significant negative correlation between plant tissue $\mathrm{Mn}$ and total earthworm abundance. Epigeic earthworm abundance had the fewest significant correlations with soil or plant chemistry of all three earthworm functional groups. Only soil extractable $\mathrm{K}$ and $\mathrm{Fe}$ showed a significant correlation with epigeic earthworm abundance (Table 3). 
Table 1 Soil and plant community shoot tissue nutrient concentration as a function of sulphurous amendment and $\mathrm{pH}$ gradient. Means with the same suffix letter indicate treatments that are not significantly different according to Kruskal-Wallis and Bonferroni post-hoc testing $(p>0.05)$. Spearman's rank order correlation of each variable against soil $\mathrm{pH}$ are also displayed with $p$ value, all significant correlation $(p<0.05)$ are displayed in bold

\begin{tabular}{|c|c|c|c|c|c|c|}
\hline \multirow[b]{2}{*}{ Variable } & \multicolumn{3}{|l|}{ Soil* } & \multicolumn{3}{|l|}{ Plant $* *$} \\
\hline & Mean \pm S.E. & & $\begin{array}{l}\text { Spearman's rank } \\
\text { order correlation } \\
(\mathrm{Vs} \mathrm{pH})\end{array}$ & Mean \pm S.E. & & $\begin{array}{l}\text { Spearman's rank } \\
\text { order correlation } \\
(\text { Vs pH) }\end{array}$ \\
\hline $\begin{array}{l}\mathrm{Al} \\
(\mathrm{mg} / \mathrm{kg})\end{array}$ & $\begin{array}{l}\text { Control } \\
\text { Elemental Sulphur } \\
\text { Ferrous sulphate }\end{array}$ & $\begin{array}{l}173.9 \pm 64.1 \mathrm{a} \\
109.3 \pm 19.4 \mathrm{a} \\
163.2 \pm 92.2 \mathrm{a}\end{array}$ & $\begin{array}{l}-0.497 \\
\boldsymbol{p}<\mathbf{0 . 0 1}\end{array}$ & $\begin{array}{l}\text { Control } \\
\text { Elemental Sulphur } \\
\text { Ferrous sulphate }\end{array}$ & $\begin{array}{l}1652.0 \pm 521.5 \mathrm{a} \\
720.0 \pm 277.7 \mathrm{~b} \\
693.6 \pm 201.4 \mathrm{ab}\end{array}$ & $\begin{array}{l}0.247 \\
p=0.215\end{array}$ \\
\hline $\begin{array}{l}\mathrm{Ca} \\
(\mathrm{mg} / \mathrm{kg})\end{array}$ & $\begin{array}{l}\text { Control } \\
\text { Elemental Sulphur } \\
\text { Ferrous sulphate }\end{array}$ & $\begin{array}{l}962.1 \pm 126.5 \mathrm{a} \\
570.5 \pm 136.7 \mathrm{~b} \\
922.5 \pm 146.5 \mathrm{ab}\end{array}$ & $\begin{array}{l}0.639 \\
\boldsymbol{p}<\mathbf{0 . 0 1}\end{array}$ & $\begin{array}{l}\text { Control } \\
\text { Elemental Sulphur } \\
\text { Ferrous sulphate }\end{array}$ & $\begin{array}{l}5342.8 \pm 498.9 \mathrm{a} \\
3375.5 \pm 446.0 \mathrm{~b} \\
4955.3 \pm 652.0 \mathrm{a}\end{array}$ & $\begin{array}{l}0.804 \\
\boldsymbol{p}<\mathbf{0 . 0 1}\end{array}$ \\
\hline $\begin{array}{l}\mathrm{Cu} \\
(\mathrm{mg} / \mathrm{kg})\end{array}$ & $\begin{array}{l}\text { Control } \\
\text { Elemental Sulphur } \\
\text { Ferrous sulphate }\end{array}$ & $\begin{array}{l}5.1 \pm 1.1 \mathrm{ab} \\
6.2 \pm 0.8 \mathrm{a} \\
3.1 \pm 0.4 \mathrm{~b}\end{array}$ & $\begin{array}{l}-0.199 \\
p=0.291\end{array}$ & $\begin{array}{l}\text { Control } \\
\text { Elemental Sulphur } \\
\text { Ferrous sulphate }\end{array}$ & $\begin{array}{l}4.4 \pm 0.5 \mathrm{a} \\
4.7 \pm 0.4 \mathrm{a} \\
1.1 \pm 0.1 \mathrm{a}\end{array}$ & $\begin{array}{l}0.129 \\
p=0.523\end{array}$ \\
\hline $\begin{array}{l}\mathrm{Fe} \\
(\mathrm{mg} / \mathrm{kg})\end{array}$ & $\begin{array}{l}\text { Control } \\
\text { Elemental Sulphur } \\
\text { Ferrous sulphate }\end{array}$ & $\begin{array}{l}264.0 \pm 44.2 \mathrm{ab} \\
211.7 \pm 24.7 \mathrm{~b} \\
334.8 \pm 47.5 \mathrm{a}\end{array}$ & $\begin{array}{l}0.102 \\
p=0.593\end{array}$ & $\begin{array}{l}\text { Control } \\
\text { Elemental Sulphur } \\
\text { Ferrous sulphate }\end{array}$ & $\begin{array}{l}1007.7 \pm 241.3 \mathrm{a} \\
659.8 \pm 152.8 \mathrm{a} \\
830.0 \pm 137.3 \mathrm{a}\end{array}$ & $\begin{array}{l}0.123 \\
p=0.540\end{array}$ \\
\hline $\begin{array}{l}\mathrm{K} \\
(\mathrm{mg} / \mathrm{kg})\end{array}$ & $\begin{array}{l}\text { Control } \\
\text { Elemental Sulphur } \\
\text { Ferrous sulphate }\end{array}$ & $\begin{array}{l}25.6 \pm 3.4 \mathrm{a} \\
45.5 \pm 10.8 \mathrm{a} \\
35.8 \pm 4.4 \mathrm{a}\end{array}$ & $\begin{array}{l}-0.282 \\
p=0.132\end{array}$ & $\begin{array}{l}\text { Control } \\
\text { Elemental Sulphur } \\
\text { Ferrous sulphate }\end{array}$ & $\begin{array}{l}7208.8 \pm 1214.5 \mathrm{a} \\
7551.9 \pm 590.6 \mathrm{a} \\
7152.8 \pm 1468.9 \mathrm{a}\end{array}$ & $\begin{array}{l}-0.151 \\
p=0.454\end{array}$ \\
\hline $\begin{array}{l}\mathrm{Mg} \\
(\mathrm{mg} / \mathrm{kg})\end{array}$ & $\begin{array}{l}\text { Control } \\
\text { Elemental Sulphur } \\
\text { Ferrous sulphate }\end{array}$ & $\begin{array}{l}54.4 \pm 9.4 \mathrm{a} \\
48.3 \pm 7.0 \mathrm{a} \\
70.4 \pm 8.0 \mathrm{a}\end{array}$ & $\begin{array}{l}0.175 \\
p=0.355\end{array}$ & $\begin{array}{l}\text { Control } \\
\text { Elemental Sulphur } \\
\text { Ferrous sulphate }\end{array}$ & $\begin{array}{l}1299.0 \pm 123.6 \mathrm{a} \\
1160.2 \pm 81.3 \mathrm{a} \\
1371.4 \pm 143.0 \mathrm{a}\end{array}$ & $\begin{array}{l}0.232 \\
p=0.244\end{array}$ \\
\hline $\begin{array}{l}\mathrm{Mn} \\
(\mathrm{mg} / \mathrm{kg})\end{array}$ & $\begin{array}{l}\text { Control } \\
\text { Elemental Sulphur } \\
\text { Ferrous sulphate }\end{array}$ & $\begin{array}{l}3.1 \pm 1.2 \mathrm{a} \\
2.9 \pm 0.8 \mathrm{a} \\
4.4 \pm 1.0 \mathrm{a}\end{array}$ & $\begin{array}{l}0.413 \\
\boldsymbol{p}=\mathbf{0 . 0 2 3}\end{array}$ & $\begin{array}{l}\text { Control } \\
\text { Elemental Sulphur } \\
\text { Ferrous sulphate }\end{array}$ & $\begin{array}{l}257.4 \pm 38.8 \mathrm{a} \\
351.2 \pm 69.0 \mathrm{a} \\
229.2 \pm 36.2 \mathrm{a}\end{array}$ & $\begin{array}{l}-0.450 \\
\boldsymbol{p}=\mathbf{0 . 0 1 9}\end{array}$ \\
\hline $\begin{array}{l}\mathrm{P} \\
(\mathrm{mg} / \mathrm{kg})\end{array}$ & $\begin{array}{l}\text { Control } \\
\text { Elemental Sulphur } \\
\text { Ferrous sulphate }\end{array}$ & $\begin{array}{l}15.4 \pm 1.5 \mathrm{a} \\
17.3 \pm 3.2 \mathrm{a} \\
17.7 \pm 2.2 \mathrm{a}\end{array}$ & $\begin{array}{l}0.364 \\
p=0.048\end{array}$ & $\begin{array}{l}\text { Control } \\
\text { Elemental Sulphur } \\
\text { Ferrous sulphate }\end{array}$ & $\begin{array}{l}1690.9 \pm 259.7 \mathrm{a} \\
1770.8 \pm 133.5 \mathrm{a} \\
2065.0 \pm 436.5 \mathrm{a}\end{array}$ & $\begin{array}{l}0.144 \\
p=0.474\end{array}$ \\
\hline $\begin{array}{l}\mathrm{S} \\
(\mathrm{mg} / \mathrm{kg})\end{array}$ & $\begin{array}{l}\text { Control } \\
\text { Elemental Sulphur } \\
\text { Ferrous sulphate }\end{array}$ & $\begin{array}{l}8.1 \pm 1.0 \mathrm{a} \\
9.8 \pm 1.8 \mathrm{a} \\
9.6 \pm 1.2 \mathrm{a}\end{array}$ & $\begin{array}{l}0.193 \\
p=0.306\end{array}$ & $\begin{array}{l}\text { Control } \\
\text { Elemental Sulphur } \\
\text { Ferrous sulphate }\end{array}$ & $\begin{array}{l}1532.9 \pm 108.9 \mathrm{a} \\
1380.4 \pm 71.0 \mathrm{a} \\
1522.2 \pm 197.5 \mathrm{a}\end{array}$ & $\begin{array}{l}0.384 \\
\boldsymbol{p}=\mathbf{0 . 0 4 8}\end{array}$ \\
\hline $\begin{array}{l}\text { Total N } \\
(\%)\end{array}$ & $\begin{array}{l}\text { Control } \\
\text { Elemental Sulphur } \\
\text { Ferrous sulphate }\end{array}$ & $\begin{array}{l}0.2 \pm 0.0 \mathrm{a} \\
0.2 \pm 0.0 \mathrm{a} \\
0.2 \pm 0.0 \mathrm{a}\end{array}$ & $\begin{array}{l}0.129 \\
p=0.498\end{array}$ & & & \\
\hline $\begin{array}{l}\text { Total C } \\
(\%)\end{array}$ & $\begin{array}{l}\text { Control } \\
\text { Elemental Sulphur } \\
\text { Ferrous sulphate }\end{array}$ & $\begin{array}{l}3.5 \pm 0.3 \mathrm{a} \\
3.9 \pm 0.4 \mathrm{a} \\
4.2 \pm 0.4 \mathrm{a}\end{array}$ & $\begin{array}{l}-0.002 \\
p=0.992\end{array}$ & & & \\
\hline C:N Ratio & $\begin{array}{l}\text { Control } \\
\text { Elemental Sulphur } \\
\text { Ferrous sulphate }\end{array}$ & $\begin{array}{l}19.0 \pm 1.2 \mathrm{a} \\
20.9 \pm 1.7 \mathrm{a} \\
18.2 \pm 0.9 \mathrm{a}\end{array}$ & $\begin{array}{l}-0.412 \\
\boldsymbol{p}=\mathbf{0 . 0 2 4}\end{array}$ & & & \\
\hline
\end{tabular}

*Soil nutrients are Mehlich III extractable concentrations, unless otherwise stated

***Plant tissue nutrients are total concentrations 
Table 2 ANOSIM pairwise tests of soil and plant community tissue chemistry. R and $p$ value generated by ANOSIM conducted on resemblance matrix of data presented in Table 1

\begin{tabular}{|c|c|c|c|c|}
\hline \multirow[b]{2}{*}{ ANOSIM Pairwise Test } & \multicolumn{2}{|l|}{ Soil } & \multicolumn{2}{|l|}{ Plant } \\
\hline & $\mathrm{R}$ & $p$ value & $\mathrm{R}$ & $p$ value \\
\hline $\begin{array}{l}\text { Control vs } \\
\text { Elemental Sulphur }\end{array}$ & 0.211 & 0.023 & -0.05 & 0.750 \\
\hline $\begin{array}{l}\text { Control vs } \\
\text { Ferrous Sulphate }\end{array}$ & 0.035 & 0.262 & -0.03 & 0.653 \\
\hline $\begin{array}{l}\text { Elemental Sulphur vs } \\
\text { Ferrous Sulphate }\end{array}$ & 0.188 & 0.019 & -0.09 & 0.956 \\
\hline
\end{tabular}

Significant differences $(p<0.05)$ are displayed in bold

Five species of adult earthworm were identified across the soil blocks. These were: Lumbricus rubellus (epigeic); Allolobophora chlorotica (endogeic); Aporrectodea caliginosa (endogeic); Aporrectodea longa (anecic); and Lumbricus terrestris (anecic). The relationship between the abundance of each species and the abiotic soil properties can be found in the supplementary information (Table S1 and S2). There was no treatment effect on species richness or Simpson and Shannon diversity indices for adult earthworms (Table S2) or for any of the species individually, with the exception of acid intolerant Allolobophora chlorotica, which was significantly reduced in the elemental sulphur treatment compared to the control and had a positive correlation with the soil $\mathrm{pH}$ gradient (Table S1). No adult species richness or Simpson and Shannon index diversity was significantly correlated to $\mathrm{pH}$ (Table S2). Juvenile earthworms were not identified to species level. There was also no significant treatment effect found in multivariate MDS and ANOSIM analysis of adult earthworm species (data not shown).

In contrast to earthworm populations, there were no significant correlations between soil $\mathrm{pH}$ and total nematode abundance or the abundance of any nematode functional group (Table 4). However, there was a significant treatment effect, with a significantly higher total abundance of nematodes in the ferrous sulphate treatment compared to the elemental sulphur treatment. This effect was a result of significantly higher numbers of both bacterial and fungal feeders in the ferrous sulphate treatment, compared to the elemental sulphur treatment (Table 4). There were also significantly fewer nematodes in total in the elemental sulphur treatment than the control. However, there was no significant reduction in any particular functional group when elemental sulphur was applied to the control. Significant negative correlations were found between soil $\mathrm{Cu}$ concentration and the total bacterial feeding and fungal feeding nematode abundance (Table 4). Shoot biomass (and therefore total biomass) was also significantly negatively correlated with abundance of fungal feeders and omnivores.

Whether abundance is examined as a treatment effect or as a correlation between $\mathrm{pH}$ and abundance, the results suggested that $\mathrm{pH}$, as imposed by sulphurous amendments, did not significantly influence rotifer or tardigrade abundance (Table 5).

\section{Biological indices}

Table 6 shows the calculated nematode (1-ITD) and earthworm (QBS-e) indices, both of which are based on functional groups rather than species. A significant treatment effect was only observed for QBS-e, with a significantly lower earthworm QBS-e in the elemental sulphur treatment. There was no treatment effect seen for the nematode 1ITD index.

Both indices significantly correlated with soil $\mathrm{pH}$ (Table 6). However, while earthworm QBS-e increased with increasing $\mathrm{pH}$, conversely, the nematode 1-ITD decreased. There was a significant negative correlation between nematode 1-ITD and both total nematode abundance, and bacterial feeder abundance $\left(r_{s}=-0.436\right.$ and $r_{s}=-0.616$ respectively, $p<0.05$, data not shown).

Results synthesis

Effect of sulphurous amendment compared to control soil blocks

There was no single variable that differed significantly between the ferrous sulphate and control treatments according to Kruskal-Wallis and Bonferroni post-hoc testing $(p>0.05)$. Characteristics that were altered as a result of elemental sulphur application are summarised in Fig. 4. 
Fig. 3 Effect of $\mathrm{pH}$ on total plant biomass a Root and shoot biomass according to sulphurous treatment. Error bars for standard error $(n=10)$. Letters in boxes denote treatments that are not statistically different according to Kruskal-Wallis and Bonferroni post-hoc testing $(p>0.05)$; b Root:Shoot ratio across $\mathrm{pH}$ gradient. Spearman's rank order correlation $=0.638, p<0.01(n=30)$
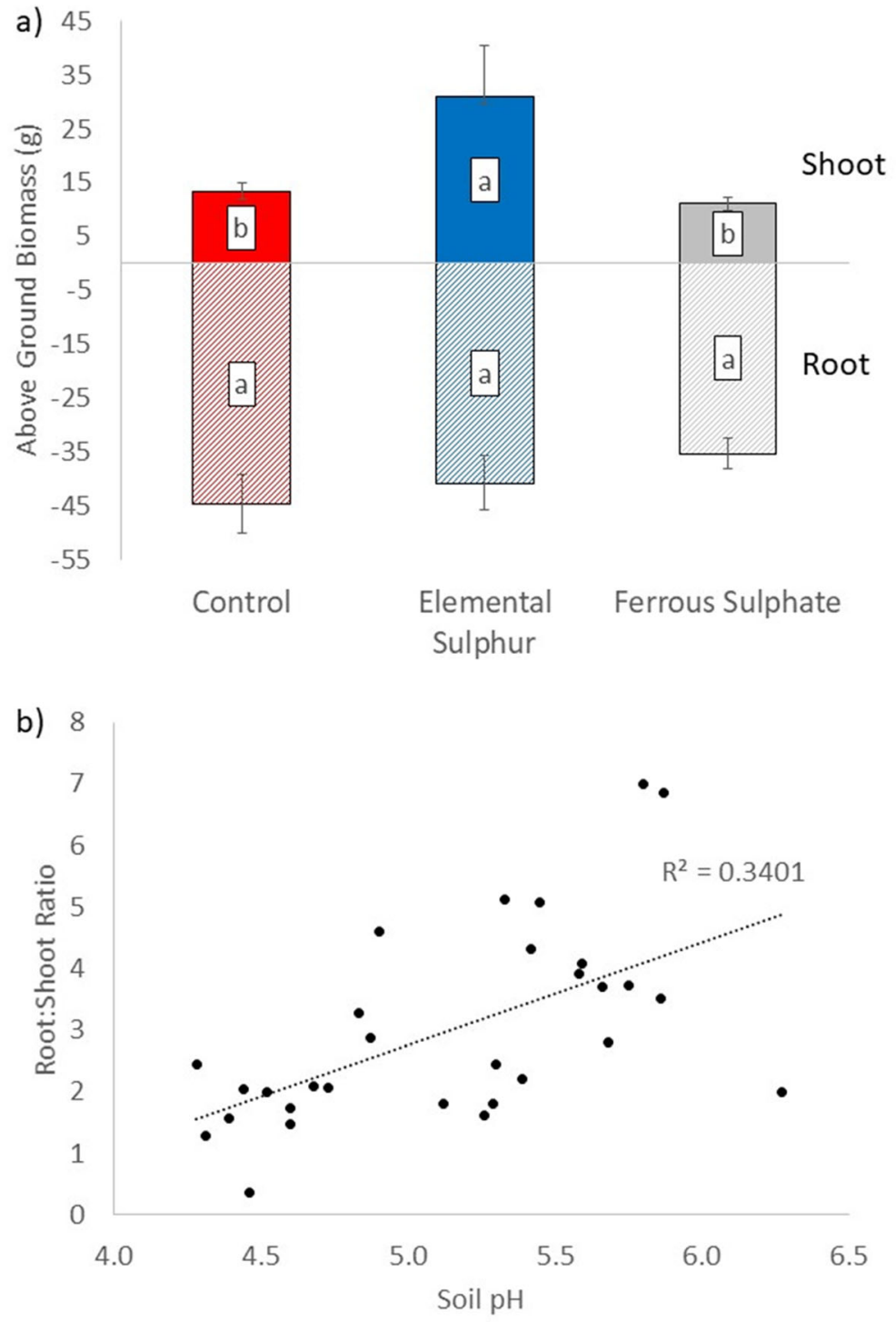

Difference between soil treated with different sulphurous amendments

\section{Discussion}

Soil chemistry altered by acidifying treatment

Although there were no differences between ferrous sulphate and the control, there were some significant differences between ferrous sulphate and elemental sulphur treated soils, summarised in Fig. 5.

\section{Effect of pH gradient}

Table 7 shows soil chemistry, plant biomass, plant tissue elemental composition and soil fauna parameters that significantly correlated $(p<0.05)$ with $\mathrm{pH}$.
Soil chemistry was significantly altered as a result of acidifying treatment, but only in the case of elemental sulphur. Soil $\mathrm{pH}$ reduction in experimental sulphur treated plots has been demonstrated in the past on these plots (Tibbett et al. 2019; Tibbett and Diaz 2005) and elsewhere (Lawson et al. 2004; Owen et al. 1999; Owen and Marrs 2000; van der Bij et al. 2018). This reduction in soil $\mathrm{pH}$ led to a subsequent significant reduction in extractable $\mathrm{Ca}$ in the soil of the elemental sulphur treatment compared to the control, reiterated by the 


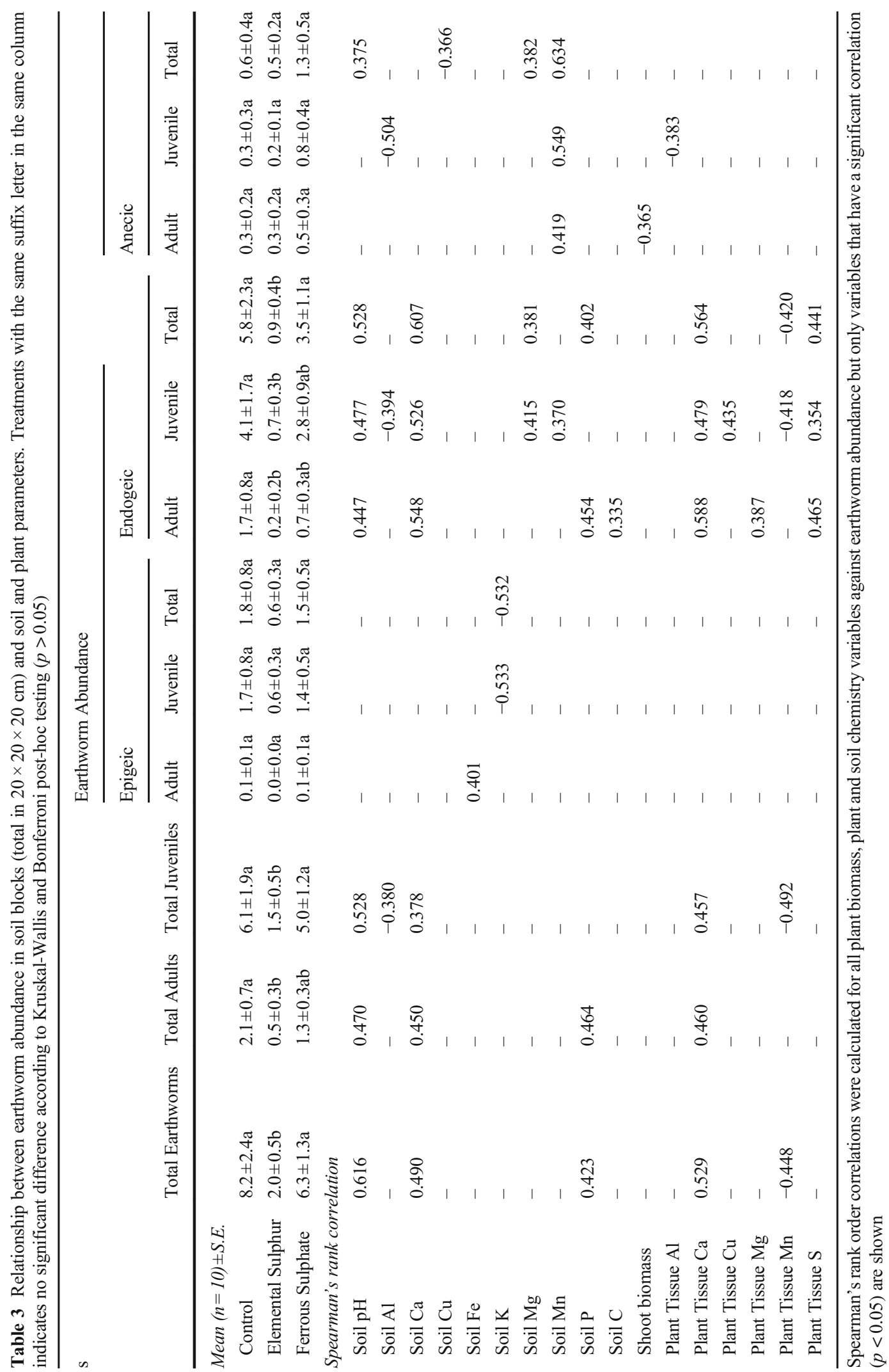


Table 4 Relationship between nematode abundance in soil blocks (total in $20 \times 20 \times 20 \mathrm{~cm}$ ) and soil and plant parameters. Treatments with the same prefix letter in the same column indicates no significant difference according to Kruskal-Wallis and Bonferroni post-hoc testing $(p>0.05)$

Nematode Abundance (100 g DWE)

\begin{tabular}{lllllll}
\multicolumn{7}{c}{ Nematode Abundance (100 g DWE) } \\
\cline { 2 - 7 } & Total & Plant Parasite & Bacterial Feeder & Fungal Feeder & Omnivore & Predator \\
\hline Mean $(n=10) \pm$ S.E. & & & & & & \\
Control & $1434.5 \pm 363.3 \mathrm{a}$ & $572.7 \pm 136.6 \mathrm{a}$ & $715.9 \pm 274.0 \mathrm{ab}$ & $89.2 \pm 24.7 \mathrm{ab}$ & $47.3 \pm 16.6 \mathrm{a}$ & $9.3 \pm 5.3 \mathrm{a}$ \\
Elemental Sulphur & $705.9 \pm 169.2 \mathrm{~b}$ & $300.4 \pm 75.1 \mathrm{a}$ & $297.9 \pm 82.4 \mathrm{~b}$ & $61.8 \pm 24.7 \mathrm{~b}$ & $36.0 \pm 12.8 \mathrm{a}$ & $9.7 \pm 3.4 \mathrm{a}$ \\
Ferrous Sulphate & $1546.1 \pm 234.5 \mathrm{a}$ & $494.1 \pm 148.6 \mathrm{a}$ & $857.5 \pm 188.7 \mathrm{a}$ & $127.6 \pm 24.2 \mathrm{a}$ & $39.4 \pm 10.2 \mathrm{a}$ & $27.6 \pm 20.2 \mathrm{a}$ \\
Spearman's rank correlation & - & & & & & \\
Soil pH & 0.391 & - & - & - & - & - \\
Soil C & 0.389 & - & - & 0.570 & - & - \\
Soil N & -0.513 & - & - & -0.555 & - & - \\
Soil Cu & - & - & -0.557 & -0.382 & - & - \\
Soil Fe & 0.584 & - & - & - & - & -0.335 \\
Soil Mg & - & - & 0.700 & - & 0.585 & - \\
Soil Mn & 0.399 & - & - & - & - & - \\
Plant Tissue Ca & - & - & - & - & - & - \\
Plant Tissue K & -6.650 & - & 0.700 & - & 0.397 & - \\
Plant Tissue Mg & - & - & 0.490 & - & 0.635 & - \\
Plant Tissue P & - & - & - & -0.516 & -0.364 & - \\
Shoot Biomass & - & - & - & -0.422 & -0.374 & - \\
Total Plant Biomass & - & - & - & 0.404 & - & - \\
Root:Shoot & 0.441 & - & - & - & - \\
\hline
\end{tabular}

Spearman's rank order correlations were calculated for all plant biomass, plant and soil chemistry variables against nematode abundance but only variables that have a significant correlation $(p<0.05)$ are shown

significant correlation between $\mathrm{pH}$ and extractable $\mathrm{Ca}$. Reduced availability of base cations, such as calcium, with acidification is a result of cation exchange with $\mathrm{H}^{+}$ occurring as an acid-buffering mechanism, leading to release of bound cations and eventual leaching from the system (Xu et al. 2020; Zhang et al. 2016).

Elemental sulphur treated soil had significantly lower concentrations of $\mathrm{Fe}$ than the ferrous sulphate treated soil, which is to be expected given the Fe content of the ferrous sulphate. The concentration of extractable $\mathrm{Cu}$ was significantly lower in the ferrous sulphate treated soils than the elemental sulphur treated soils, despite the lower $\mathrm{pH}$ in the elemental sulphur treated soils. A possible explanation for this observation is that, ferrous sulphate application may contain increased $\mathrm{Fe}$ oxide or oxyhydroxide concentrations, resulting in increased $\mathrm{Cu}$ sorption (Nachtigall et al. 2007).

Univariate analysis of the soil's chemistry may not resolve overall differences in the chemical environment, a key part of the habitat, in which soil organisms and plant reside. While other individual soil chemical parameters did not vary significantly between elemental sulphur and the control, multivariate analysis of soil chemical parameters revealed elemental sulphur treated soil was significantly different to the control and ferrous sulphate treated soil.

Across the $\mathrm{pH}$ gradient, regardless of treatment, soil extractable $\mathrm{Ca}, \mathrm{Al}$ and $\mathrm{P}$ were significantly and positively correlated with $\mathrm{pH}$. The positive correlation between extractable $\mathrm{Ca}$ and $\mathrm{pH}$, could be a result of $\mathrm{H}^{+}$ during acidification competing with $\mathrm{Ca}$ for binding sites (discussed above). This could be further perpetuated by a higher $\mathrm{Al}^{3+}$ ions, which are more soluble in acidic conditions, competing with base cations for binding sites (Lucas et al. 2011), in turn leading to loss of calcium through leaching.

Acidification is often associated with an increase in extractable Mn (Kidd and Proctor 2001) and a decrease 
Table 5 Relationship between rotifer and tardigrade abundance in soil blocks (total in $20 \times 20 \times 20 \mathrm{~cm}$ ) and soil and plant parameters

\begin{tabular}{lll}
\hline & \multicolumn{2}{l}{ Total Abundance (100 g DWE) } \\
\cline { 2 - 3 } & Rotifers & Tardigrades \\
\hline Mean $(n=10) \pm$ S.E. & $12.0 \pm 5.4 \mathrm{a}$ & $1.2 \pm 0.8 \mathrm{a}$ \\
Control & $10.8 \pm 3.9 \mathrm{a}$ & $1.2 \pm 0.6 \mathrm{a}$ \\
Elemental Sulphur & $8.9 \pm 1.8 \mathrm{a}$ & $1.3 \pm 0.6 \mathrm{a}$ \\
Ferrous Sulphate & - & \\
Spearman's rank correlation & - \\
Soil pH & -0.462 & - \\
Soil Fe & - & 0.371 \\
Soil Mg & -0.480 & - \\
Plant Tissue Al & -0.443 & - \\
Plant Tissue Fe & 0.498 & - \\
Plant Tissue K & - & -0.336 \\
Root Biomass & & \\
\hline
\end{tabular}

Treatments with the same prefix letter in the same column indicates no significant difference according to Kruskal-Wallis and Bonferroni post-hoc testing ( $p>0.05$ Spearman's rank order correlations were calculated for all plant biomass, plant and soil chemistry variables against rotifer and tardigrade abundance but only variables that have a significant correlation $(p<0.05)$ are shown

in available P (Ch'ng et al. 2014). In our research the reverse was found, extractable Mn increased significantly with $\mathrm{pH}$, and extractable $\mathrm{P}$ decreased. The increase in extractable $\mathrm{P}$ in the low $\mathrm{pH}$ samples has been observed in previous studies on this site, and is likely a result of acidification causing a release of $\mathrm{P}$ from historical rock phosphate amendments during agricultural improvement (Tibbett et al. 2019; Tibbett and Diaz 2005). The mobilisation of $\mathrm{P}$ and $\mathrm{Mn}$ in the rhizosphere takes place though a similar mechanism. In a naturally low $\mathrm{pH}$ system, low extractable $\mathrm{P}$ in the soil promotes plants to release exudates to mobilise $\mathrm{P}$, which results in the coliberation of Mn (Alejandro et al. 2020). This has not happened in our research because our low $\mathrm{pH}$ soils, as discussed, have an excess of extractable P. Therefore, the release of exudates would not occur to liberate $\mathrm{P}$ and, inadvertently mobilise Mn.

\section{Plant biomass and elemental composition}

The elemental sulphur treatment resulted in a higher shoot biomass than ferrous sulphate treatment and the control. Moreover, there was a relationship between $\mathrm{pH}$
Table 6 Relationship between earthworm and nematode diversity index in soil blocks (total in $20 \times 20 \times 20 \mathrm{~cm}$ ) soil and plant parameters. Treatments with the same suffix letter in the same column indicates no significant difference according to KruskalWallis and Bonferroni post-hoc testing $(p>0.05)$

\begin{tabular}{lll}
\hline & Earthworm QBS-e & Nematode 1-ITD \\
\hline Mean $(n=10) \pm$ S.E. & & \\
Control & $689.0 \pm 194.0 \mathrm{a}$ & $0.55 \pm 0.03 \mathrm{a}$ \\
Elemental Sulphur & $255.3 \pm 70.0 \mathrm{~b}$ & $0.56 \pm 0.03 \mathrm{a}$ \\
Ferrous Sulphate & $706.0 \pm 160.0 \mathrm{a}$ & $0.50 \pm 0.04 \mathrm{a}$ \\
Spearman's rank correlation & \\
pH & 0.606 & -0.515 \\
Soil Al & - & 0.563 \\
Soil Ca & 0.434 & - \\
Soil Cu & - & - \\
Soil Mg & 0.368 & - \\
Soil Mn & 0.495 & -0.578 \\
Soil P & - & -0.422 \\
Plant Tissue Ca & - & -0.488 \\
Plant Tissue Mg & - & -0.363 \\
Plant Tissue P & - & -0.522
\end{tabular}

Spearman's rank order correlations were calculated for all plant biomass, plant and soil chemistry variables against diversity index but only variables that have a significant correlation $(p<0.05)$ are shown

and plant dry matter partitioning, with roots contributing more to total biomass with increasing $\mathrm{pH}$. Plants species on the soil blocks were not identified, so it is uncertain whether differences in biomass are a result of changes in growth rates of the same plants, or a shift to different plant species that have different growth patterns. However, vegetation surveys on the plots in 2014 revealed a different vegetational assemblage on the elemental sulphur plots, compared to the control and ferrous sulphate plots (Tibbett et al. 2019). Acidity is known to inhibit root development, largely as a result of increased $\mathrm{Al}$ solubility (Edwards 1991; Pavlů et al. 2019). Highlighted by the significant reduction in root biomass with increasing extractable $\mathrm{Al}$ in our data (Spearman's rank order correlations $=-0.407, p<0.05$, data not shown), and extractable $\mathrm{Al}$, in turn, was significantly negatively correlated with soil $\mathrm{pH}$.

Within plant community shoot biomass, only $\mathrm{Al}$ and $\mathrm{Ca}$ had a significant response to sulphurous amendment treatment. Although there was no treatment effect found for available $\mathrm{Al}$ in the soil, the concentrations of $\mathrm{Al}$ in shoot tissue from plants in the elemental sulphur treated 
Fig. 4 Graphical summary of the significant effects of elemental sulphur application on control soil chemistry, plant biomass, plant tissue elemental composition and soil fauna. Only significant differences between elemental sulphur treated blocks and control blocks (according to KruskalWallis and Bonferroni post host testing $(p<0.05)$ are shown. There were no significant differences between the control blocks and ferrous sulphate treated blocks
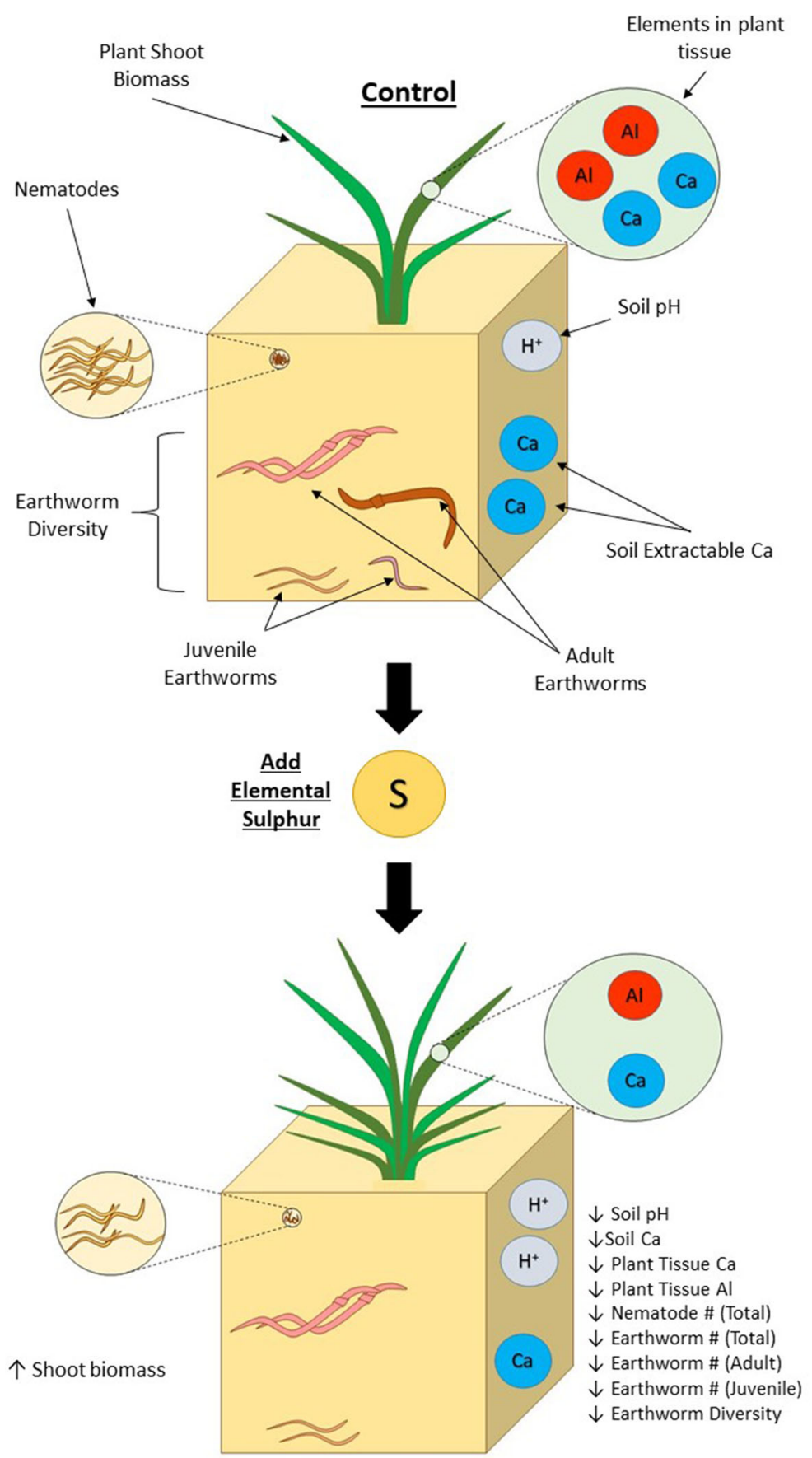

soils were reduced compared to the plants from the control. Only plant tissue $\mathrm{Ca}$ and $\mathrm{S}$ concentration had a positive correlation with soil $\mathrm{pH}$, whilst plant tissue Mn concentration was negatively correlated with soil $\mathrm{pH}$. This negative relationship between plant tissue $\mathrm{Mn}$ concentration and soil $\mathrm{pH}$ contrasts with the relationship between soil extractable $\mathrm{Mn}$ and soil $\mathrm{pH}$. It has been suggested that soil Mn availability is controlled by neither soil nor plant characteristics but by the combined effects of soil properties, plant characteristics, and the interactions in the rhizosphere (Godo and Reisenauer 1980). Negative effects of elevated extractable P on 
Fig. 5 Graphical summary of the significant differences between elemental sulphur and ferrous sulphate treatment on soil chemistry, plant biomass, plant tissue elemental composition and soil fauna. Only significant differences between elemental sulphur treated blocks and ferrous sulphate treated blocks (according to Kruskal-Wallis and Bonferroni post host testing $(p<0.05)$ are shown. There were no significant differences between the control blocks and ferrous sulphate treated blocks
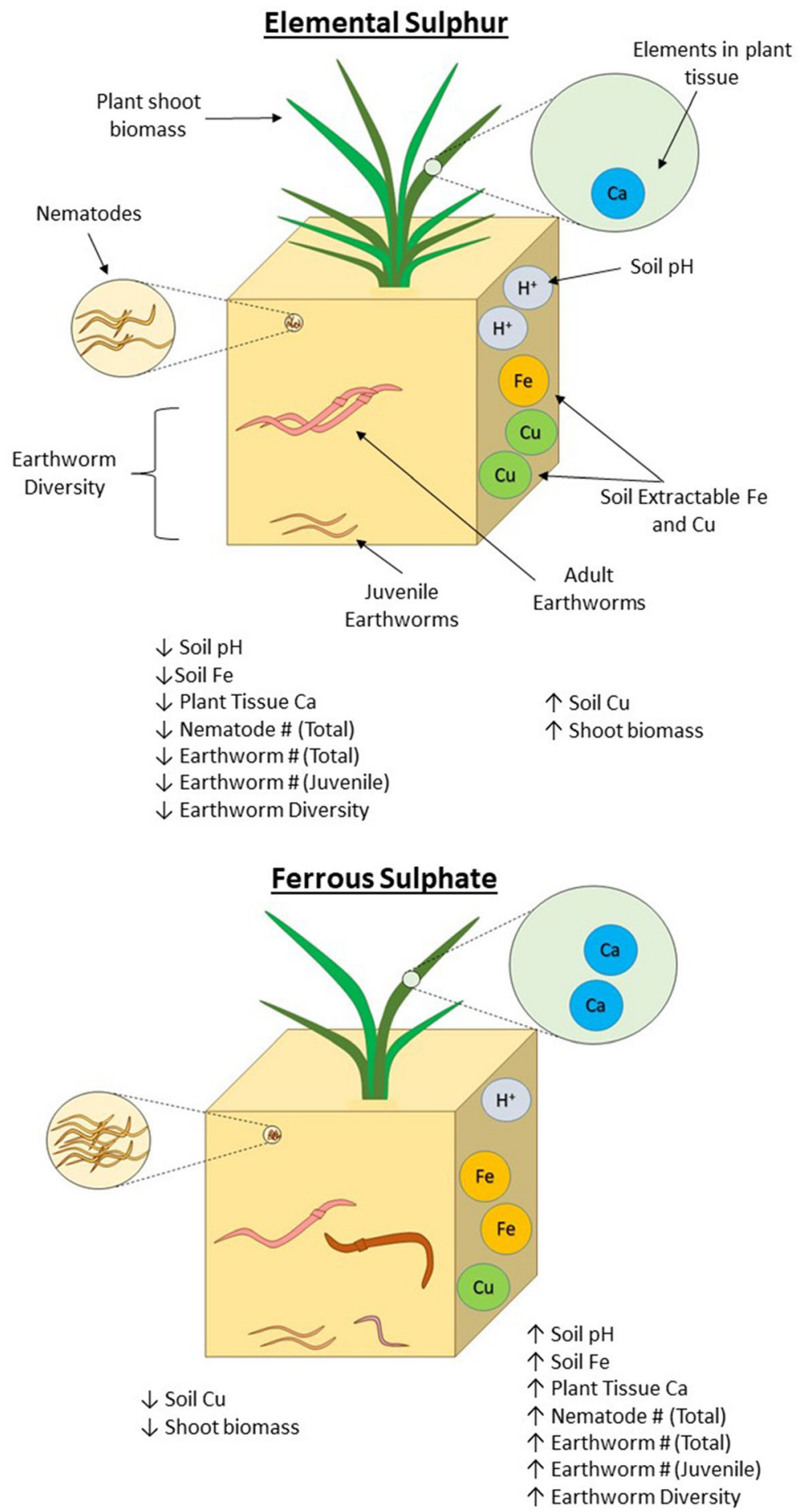

plant tissue Mn accumulation have been observed in barley and wheat due to $\mathrm{P}$ interference directly with $\mathrm{Mn}$ at the uptake and/or translocation level (Neilsen et al. 1992; Pedas et al. 2011; Racz and Haluschak
1974). This suggests that the presence of extractable $P$ in this system is impacting both the presence of extractable Mn (discussed above), and the plants ability to absorb it. 
Table 7 Soil chemistry, plant biomass, plant tissue elemental composition and soil fauna variables that are significantly correlated with pH

\begin{tabular}{|c|c|c|}
\hline Variable & Significant positive correlation with $\mathrm{pH}$ & Significant negative correlation with $\mathrm{pH}$ \\
\hline Soil Al & & $\sqrt{ }$ \\
\hline Soil Ca & $\sqrt{ }$ & \\
\hline Soil Mn & $\sqrt{ }$ & \\
\hline Soil P & $\sqrt{ }$ & \\
\hline Soil C:N & & $\sqrt{ }$ \\
\hline Shoot biomass & & $\sqrt{ }$ \\
\hline Root:Shoot & $\sqrt{ }$ & \\
\hline Plant Tissue $\mathrm{Ca}$ & $\sqrt{ }$ & \\
\hline Plant Tissue Mn & & $\sqrt{ }$ \\
\hline Plant Tissue $\mathrm{S}$ & $\sqrt{ }$ & \\
\hline Total earthworm abundance & $\sqrt{ }$ & \\
\hline Total adult earthworm abundance & $\sqrt{ }$ & \\
\hline Total juvenile earthworm abundance & $\sqrt{ }$ & \\
\hline Total endogeic earthworm abundance & $\sqrt{ }$ & \\
\hline Total endogeic adult earthworm abundance & $\sqrt{ }$ & \\
\hline Total endogeic juvenile earthworm abundance & $\sqrt{ }$ & \\
\hline Total anecic earthworm abundance & $\sqrt{ }$ & \\
\hline Earthworm diversity (QBS-e) & $\sqrt{ }$ & \\
\hline Nematode Diversity (1-ITD) & & $\sqrt{ }$ \\
\hline
\end{tabular}

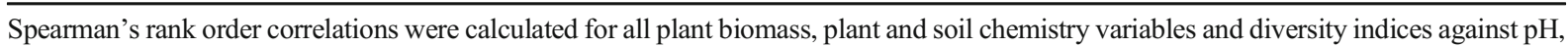
but only variables that have a significant correlation $(p<0.05)$ are shown

Soil fauna abundance and biological indices

Reduction in earthworm abundance with decreased soil pH has been well documented (Curry 2004; De Wandeler et al. 2016; Huhta et al. 1986; Phillips et al. 2019; Singh et al. 2016). Total earthworm abundance in our research, was significantly affected by sulphurous amendment, with fewer earthworms found in soil treated with elemental sulphur when compared to the ferrous sulphate treated or control soil. In addition, total abundance of earthworms significantly decreased with acidification. The only other variables that were significantly correlated with total earthworm abundance (extractable $\mathrm{P}$ and $\mathrm{Ca}$, and plant tissue $\mathrm{Ca}$ ) were all significantly affected by soil $\mathrm{pH}$ (discussed above) suggesting confounding effects of extractable $\mathrm{P}, \mathrm{Ca}$ and $\mathrm{pH}$ on earthworm abundance. However, only the endogeic and anecic earthworms were affected by sulphurous amendment or the soil $\mathrm{pH}$ gradient. Epigeic earthworms feed on plant litter at the soil surface above the mineral layer, whereas anecic and endogeic earthworms burrow deeper into the mineral soil, suggesting they are more susceptible to abiotic soil properties, and less tolerant to a reduction in soil pH (Blouin et al. 2013; Lavelle et al. 1995; Menta 2012; Pulleman et al. 2012; Sizmur et al. 2011). Earthworms are directly sensitive to soil $\mathrm{pH}$, but tolerance varies between species (Springett and Syers 1984). For example, Allolobophora chlorotica (endogeic), the only earthworm species identified to have a significant positive correlation between abundance and $\mathrm{pH}$ is known to be intolerant of acidic soil conditions (McCallum et al. 2016). Different earthworm species, or functional groups, being impacted by $\mathrm{pH}$ in different ways had led to significant effects on the earthworm community composition. The QBS-e index showed both a significant treatment effect, and a significant positive relationship with soil $\mathrm{pH}$. The elemental sulphur plots, which had an altered soil chemistry, shoot biomass and shoot chemistry, in turn, had a significantly lower QBS-e compared to the ferrous sulphate and control treatments.

As with earthworm abundance, a treatment effect was observed for total nematode abundance with a lower total abundance in the elemental sulphur 
treatment when compared to the ferrous sulphate treatment and control. Positive correlations between $\mathrm{pH}$ and total nematode abundance have often been reported (Holland et al. 2018; Neher et al. 2005), but a significant relationship was not found in our data. As discussed by Neher (2001), unlike earthworms, nematodes are ubiquitous and often persist when other organisms are lost as a result of disturbance or pollution. This may account for why soil $\mathrm{pH}$ was significantly correlated with total earthworm abundance, but not nematode abundance.

Biodiversity, in terms of species richness, is not as informative as a soil biological indicators based on the life strategy of key species (Moura and Franzener 2017), which is why we employed the QBS-e and nematode 1ITD rather than indices based on the number of species present. The use of the QBS-e in the present study appears, in the context of soil $\mathrm{pH}$ effect on earthworm communities, to confirm this, as there was no significant relationship between soil $\mathrm{pH}$ and adult species diversity. Moreover, not all individual earthworm functional groups were significantly impacted by the acidifying treatments, or the $\mathrm{pH}$ gradient. The QBS-e index, which encompassed all groups and maturity, was significantly impacted by both sulphur treatment and the $\mathrm{pH}$ gradient, demonstrating the efficacy of this index in indicating change in earthworm communities in response to altered soil parameters.

Contrary to observations for earthworms, nematode abundance was not influenced by the $\mathrm{pH}$ gradient. This was the case for total abundance and for the abundance of individual nematode functional groups considered alone. There was, however, a significantly lower total abundance of nematodes in the elemental sulphur treatment compared to both the ferrous sulphate treatment and the control. There were also significantly higher numbers of both bacterial and fungal feeders in the ferrous sulphate treatment compared to the elemental sulphur treatment. This resulted in an unexpected decline in nematode 1-ITD with increasing $\mathrm{pH}$. In all soil treatments, bacterial feeders were among the largest contributors to the total nematode population. Therefore, a decrease in bacterial feeders (if other groups are maintained or reduced to a lesser extent) will raise the relative proportion that the other trophic groups contribute, thereby raising the diversity. Hence as the abundance of bacterial feeders increases, the diversity of nematodes decreases. Bacterial feeder abundance was the only trophic group of nematodes that were significantly correlated with 1-ITD (Spearman's rank order correlations $=-0.450, p<0.05$, data not shown).

A significant negative correlation was found between soil $\mathrm{Cu}$ concentration and both total nematode and bacterial feeder abundance. Total nematode, bacterial feeder and fungal feeder abundance was also significantly reduced in the elemental sulphur treatment, which had elevated available soil $\mathrm{Cu}$ compared to the ferrous sulphate treatment. This may indicate that $\mathrm{Cu}$ toxicity contributed to the nematode decline. A negative effect of $\mathrm{Cu}$ on soil nematode abundance has been reported (Korthals et al. 2000; Turbé et al. 2010). Whilst $\mathrm{Cu}$ concentrations in the sulphur treated soils were well below reported lethal concentration to $50 \%$ of nematodes $\left(\mathrm{LC}_{50}\right)$ values $(31-162 \mathrm{mg} / \mathrm{kg})$, there may be sublethal effects (Boyd and Williams 2003).

Nematodes occupy multiple levels of the soil food web (as primary, secondary and/or tertiary consumers). It has been suggested by Turbé et al. (2010) that the abundance of the different trophic groups of nematodes, or community composition, are more sensitive to change than the total abundance. Therefore, analysis of the community structure, at a trophic level, gives an indication of soil disturbance, and could be useful in establishing management targets in unique or ecologically valuable habitats (Bongers and Ferris 1999; Neher 2001; Neher et al. 2005). In addition, the use of functional nematode groups as indicators if soil quality in monitoring has practical benefits, not just for ease of identification, but because the effects of individual soil species on ecosystem processes is often unknown (Neher 2001).

Despite this, adoption of nematode community indices for large scale environmental monitoring has been hindered by a lack of tests across different systems (Neher et al. 2005), particularly as results are often contradictory (Turbé et al. 2010). The present study has demonstrated that nematode diversity at functional group level, i.e. 1-ITD, was able to show that the $\mathrm{pH}$ gradient had affected the nematode community in grassland, whereas measurements of abundance of both total nematodes and individual functional groups, could not. 
Functional group based biological indices are therefore effective tools for monitoring soil quality changes induced by soil acidification.

\section{Conclusions}

The use of soil blocks has allowed us to directly attribute changes in soil fauna across a contrived $\mathrm{pH}$ gradient to the abiotic conditions in which those organisms were found. Soil $\mathrm{pH}$, altered through application of sulphurous amendements has influenced the mobility of $\mathrm{Ca}$, $\mathrm{Al}, \mathrm{Mn}$ and $\mathrm{P}$, which in turn has impacted on plant tissue chemistry and plant biomass ratios. These changes in soil chemistry and vegetation have, in turn influenced the abundance and diversity of nematodes and earthworms in the soil blocks.

Biological indices based on the relative abundance of different earthworm and nematode functional groups proved to be sensitive indicators of soil $\mathrm{pH}$, whilst abundance measurements were less sensitive for earthworms and not sensitive in the case of nematodes.

Supplementary Information The online version contains supplementary material available at https://doi.org/10.1007/s11104021-04879-z.

Acknowledgements This project was part of the RECARE project (http://www.recare-project.eu/) which received funding from the European Union's Seventh Framework Programme for research, technological development and demonstration under grant agreement no 603498 . The authors would like to thank the National Trust for the use of the field site and their support, along with Martin Smith and the late Rob Haslam for their invaluable contribution to setting up the field sites and Vinícius De Oliveira for his assistance with soil and plant analysis.

Open Access This article is licensed under a Creative Commons Attribution 4.0 International License, which permits use, sharing, adaptation, distribution and reproduction in any medium or format, as long as you give appropriate credit to the original author(s) and the source, provide a link to the Creative Commons licence, and indicate if changes were made. The images or other third party material in this article are included in the article's Creative Commons licence, unless indicated otherwise in a credit line to the material. If material is not included in the article's Creative Commons licence and your intended use is not permitted by statutory regulation or exceeds the permitted use, you will need to obtain permission directly from the copyright holder. To view a copy of this licence, visit http://creativecommons.org/licenses/by/4.0/.

\section{References}

Alejandro S, Höller S, Meier B, Peiter E (2020) Manganese in plants: from acquisition to subcellular allocation. Front Plant Sci 11:1-23. https://doi.org/10.3389/fpls.2020.00300

Bardgett RD, Van Der Putten WH (2014) Belowground biodiversity and ecosystem functioning. Nature 515:505-511. https://doi.org/10.1038/nature13855

Bianchelli S, Gambi C, Mea M, Pusceddu A, Danovaro R (2013) Nematode diversity patterns at different spatial scales in bathyal sediments of the Mediterranean Sea. Biogeosciences 10:5465-5479. https://doi.org/10.5194/bg10-5465-2013

Blouin M, Hodson ME, Delgado EA, Baker G, Brussaard L, Butt KR, Dai J, Dendooven L, Peres G, Tondoh JE, Cluzeau D, Brun JJ (2013) A review of earthworm impact on soil function and ecosystem services. Eur J Soil Sci 64:161-182. https://doi.org/10.1111/ejss.12025

Bongers T, Ferris H (1999) Nematode community structure as a bioindicator in environmental monitoring. TREE 14:224 228

Boyd WA, Williams PL (2003) Comparison of the sensitivity of three nematode species to copper and their utility in aquatic and soil toxicity tests. Environ Toxicol Chem 22:2768-2774. https://doi.org/10.1897/02-573

Ch'ng HY, Ahmed OH, Majid NMA (2014) Improving phosphorus availability in an acid soil using organic amendments produced from agroindustrial wastes. Sci World J 506356: 1-6. https://doi.org/10.1155/2014/506356

Clarke KR, Gorley RN (2006) PRIMER v6: user manual/tutorial (Plymouth routines in multivariate ecological research). PRIMER-E, Plymouth

Curry JP 2004 Factors affecting the abundance of earthworms in soils. In: Edwards, C.A. (Ed.), Earthworm ecology (pp. 91108). https://doi.org/10.1201/9781420039719.pt3

De Wandeler H, Sousa-Silva R, Ampoorter E, Bruelheide H, Carnol M, Dawud SM, Dănilă G, Finer L, Hättenschwiler S, Hermy M, Jaroszewicz B, Joly FX, Müller S, Pollastrini M, Ratcliffe S, Raulund-Rasmussen K, Selvi F, Valladares F, Van Meerbeek K, Verheyen K, Vesterdal L, Muys B (2016) Drivers of earthworm incidence and abundance across European forests. Soil Biol Biochem 99:167-178. https://doi.org/10.1016/j.soilbio.2016.05.003

DEFRA (2019) British survey of Fertiliser practice: Fertiliser use on farm crops for the 2018 crop year. Department of Environment \& Rural Affairs

Diaz A, Green I, Tibbett M (2008) Re-creation of heathland on improved pasture using top soil removal and Sulphur amendments: edaphic drivers and impacts on ericoid mycorrhizas. Biol Conserv 141:1628-1635. https://doi.org/10.1016/j. biocon.2008.04.006

Doran JW, Zeiss MR (2000) Soil health and sustainibility: managing the biotic component of soil quality. Appl Soil Ecol 15: 3-11. https://doi.org/10.1016/S0929-Get

Edwards AC (1991) Soil acidity and its interactions with phosphorus availability for a range of different crop types. In: Wright RJ, Baligar VC, Murrmann R (eds) Plant-Soil Interactions at Low PH. Kluwer Academic Publishers, Dordrecht, pp 299-305. https://doi.org/10.1007/978-94011-3438-5_33 
Falco LB, Sandler R, Momo F, Di Ciocco C, Saravia L, Covialla C (2015) Earthworm assemblages in different intensity of agricultural uses and their relation to edaphic variables. Pedobiologia (Jena) 3:1-18. https://doi.org/10.7717 /peerj.979

Fusaro S, Gavinelli F, Lazzarini F, Paoletti MG (2018) Soil biological quality index based on earthworms (QBS-e). A new way to use earthworms as bioindicators in agroecosystems. Ecol Indic 93:1276-1292. https://doi. org/10.1016/j.ecolind.2018.06.007

Gadd GM (1999) Fungal production of citric and oxalic acid: importance in metal speciation, physiology and biogeochemical processes. Adv Microb Physiol 41:47-92

Godo GH, Reisenauer HM (1980) Plant effects on soil manganese availability. Soil Sci Soc Am J 44:993-995

Goulding KWT (2016) Soil acidification and the importance of liming agricultural soils with particular reference to the United Kingdom. Soil Use Manag 32:390-399. https://doi. org/10.1111/sum. 12270

Griffiths RI, Thomson BC, James P, Bell T, Bailey M, Whiteley AS (2011) The bacterial biogeography of British soils. Environ Microbiol 13:1642-1654. https://doi.org/10.1111 j.1462-2920.2011.02480.x

Hartman WH, Richardson CJ (2013) Differential nutrient limitation of soil microbial biomass and metabolic quotients (qCO2): is there a biological stoichiometry of soil microbes? PLoS One 8:e57127. https://doi.org/10.1371/journal. pone. 0057127

Holland JE, Bennett AE, Newton AC, White PJ, McKenzie BM, George TS, Pakeman RJ, Bailey JS, Fornara DA, Hayes RC (2018) Liming impacts on soils, crops and biodiversity in the UK: A review. Sci Total Environ 610-611:316-332. https://doi.org/10.1016/j.scitotenv.2017.08.020

Huhta V, Hyvonen R, Koskenniemi A, Vilkamaa P, Kaasalainen P, Sulander M (1986) Response of soil fauna to fertilization and manipulation of $\mathrm{pH}$ in coniferous forests. Acta For Fenn 195:1-30

Kidd PS, Proctor J (2001) Why plants grow poorly on very acid soils: are ecologists missing the obvious? J Exp Bot 52:791799

Korthals GW, Bongers M, Fokkema A, Dueck TA, Lexmond TM (2000) Joint toxicity of copper and zinc to a terrestrial nematode Community in an Acid Sandy Soil. Ecotoxicology 9: 219-228. https://doi.org/10.1023/A:1008950905983

Lavelle, P., Chauvel, A., Fragoso, C., 1995. Faunal activity in acid soils. In: Date RA (Ed.), Plant-soil interactions at low PH: principles and management (pp. 201-211). Kluwer academic Publishers. https://doi.org/10.1007/978-94-011-0221-6_29

Lawson CS, Ford MA, Mitchley J, Warren JM (2004) The establishment of heathland vegetation on ex-arable land: the response of Calluna vulgaris to soil acidification. Biol Conserv 116:409-416. https://doi.org/10.1016/S0006-3207(03 000233-7

Lucas RW, Klaminder J, Futter MN, Bishop KH, Egnell G, Laudon H, Högberg P (2011) A meta-analysis of the effects of nitrogen additions on base cations: implications for plants, soils, and streams. For Ecol Manag 262:95-104. https://doi. org/10.1016/j.foreco.2011.03.018

McCallum HM, Wilson JD, Beaumont D, Sheldon R, O'Brien MG, Park KJ (2016) A role for liming as a conservation intervention? Earthworm abundance is associated with higher soil $\mathrm{pH}$ and foraging activity of a threatened shorebird in upland grasslands. Agric Ecosyst Environ 223:182-189. https://doi.org/10.1016/j.agee.2016.03.005

Mehlich A (1984) Mehlich 3 soil test extractant: a modification of Mehlich 2 extractant. Commun Soil Sci Plant Anal 1:14091416

Menta C (2012) Soil Fauna diversity - function, soil degradation, biological indices, soil restoration. In: biodiversity conservation and utilization in a diverse world. IntechOpen, pp. 59-94. https://doi.org/10.5772/51091

Moura GS, Franzener G (2017) Biodiversity of nematodes biological indicators of soil quality in the agroecosystems 1-8. https://doi.org/10.1590/1808.

Nachtigall GR, Nogueirol RC, Alleoni LRF, Cambri MA (2007) Copper concentration of vineyard soils as a function of $\mathrm{pH}$ variation and addition of poultry litter. Braz Arch Biol Technol 50:941-948. https://doi.org/10.1590/S151689132007000700005

Neher D (2001) Role of nematodes in soil health and their use as indicators. J Nematol 33:161-168

Neher DA, Wu J, Barbercheck ME, Anas O (2005) Ecosystem type affects interpretation of soil nematode community measures. Appl Soil Ecol 30:47-64. https://doi.org/10.1016/j. apsoil.2005.01.002

Neilsen D, Neilsen GH, Sinclair AH, Linehan DJ (1992) Soil phosphorus status, $\mathrm{pH}$ and the manganese nutrition of wheat. Plant Soil 145:45-50

Neilson R, Caul S, Fraser FC, King D, Mitchell SM, Roberts DM, Giles ME (2020) Microbial community size is a potential predictor of nematode functional group in limed grasslands. Appl Soil Ecol 156:1-12

Neina D (2019) The role of soil $\mathrm{pH}$ in plant nutrition and soil remediation. Appl Environ Soil Sci 5794869:1-9. https://doi. org/10.1155/2019/5794869

Nielsen UN, Osler GHR, Campbell CD, Neilson R, Burslem DFRP, van der Wal R (2010) The enigma of soil animal species diversity revisited: the role of small-scale heterogeneity. PLoS One 5:1-6. https://doi.org/10.1371/journal. pone. 0011567

Owen KM, Marrs RH (2000) Acidifying arable soils for the restoration of acid grasslands. Appl Veg Sci 3:105-116. https://doi.org/10.2307/1478924

Owen KM, Marrs RH, Snow CSR, Evans CE (1999) Soil acidification - the use of Sulphur and acidic plant materials to acidify arable soils for the recreation of heathland and acidic grassland at Minsmere, UK. Biol Conserv 87:105-121

Pavlů L, Borůvka L, Drábek O, Nikodem A (2019) Effect of natural and anthropogenic acidification on aluminium distribution in forest soils of two regions in the Czech Republic. $\mathrm{J}$ For Res 1-8:363-370. https://doi.org/10.1007/s11676-01901061-1

Pedas P, Husted S, Skytte K, Schjoerring JK (2011) Elevated phosphorus impedes manganese acquisition by barley plants. Front Plant Sci 2:1-12. https://doi.org/10.3389 /fpls.2011.00037

Phillips HRP, Guerra CA, Bartz MLC, Briones MJ, Brown G, Crowther TW, Ferlian O, Gongalsky KB, Van Den Hoogen J, Krebs J, Orgiazzi A, Routh D, Schwarz B, Bach EM, Bennett J, Brose U, Decaëns T, König-Ries B, Loreau M, Mathieu J, Mulder C, Van Der Putten WH, Ramirez KS, Rillig MC, Russell D, Rutgers M, Thakur MP, De Vries FT, 
Wall DH, Wardle DA, Arai M, Ayuke FO, Baker GH, Beauséjour R, Bedano JC, Birkhofer K, Blanchart E, Blossey B, Bolger T, Bradley RL, Callaham MA, Capowiez Y, Caulfield ME, Choi A, Crotty FV, Dávalos A, Cosin DJD, Dominguez A, Duhour AE, Van Eekeren N, Emmerling C, Falco LB, Fernández R, Fonte SJ, Fragoso C, Franco ALC, Fugère M, Fusilero AT, Gholami S, Gundale MJ, Lopez M, Nica G, Hackenberger DK, Hernández LM, Hishi T, Holdsworth AR, Holmstrup M, Hopfensperger KN, Lwanga EH, Huhta V, Hurisso TT, Iannone BV, Iordache M, Joschko M, Kaneko N, Kanianska R, Keith AM, Kelly CA, Kernecker ML, Klaminder J, Koné AW, Kooch Y, Kukkonen ST, Lalthanzara H, Lammel DR, Lebedev IM, Li Y, Lidon JBJ, Lincoln NK, Loss SR, Marichal R, Matula R, Moos JH, Moreno G, Morn-Ríos A, Muys B, Neirynck J, Norgrove L, Novo M, Nuutinen V, Nuzzo V, Mujeeb Rahman P, Pansu J, Paudel S, Pérès G, PérezCamacho L, Piñeiro R, Ponge JF, Rashid MI, Rebollo S, Rodeiro-Iglesias J, Rodríguez M, Roth AM, Rousseau GX, Rozen A, Sayad E, Van Schaik L, Scharenbroch BC, Schirrmann M, Schmidt O, Schröder B, Seeber J, Shashkov MP, Singh J, Smith SM, Steinwandter M, Talavera JA, Trigo D, Tsukamoto J, De Valença AW, Vanek SJ, Virto I, Wackett AA, Warren MW, Wehr NH, Whalen JK, Wironen MB, Wolters V, Zenkova IV, Zhang W, Cameron EK, Eisenhauer N (2019) Global distribution of earthworm diversity. Science 366:480-485. https://doi.org/10.1126 /science.aax4851

Pulleman M, Creamer R, Hamer U, Helder J, Pelosi C, Pérès G, Rutgers M (2012) Soil biodiversity, biological indicators and soil ecosystem services-an overview of European approaches. Curr Opin Environ Sustain 4:529-538. https://doi.org/10.1016/j.cosust.2012.10.009

Racz GJ, Haluschak PW (1974) Effects of phosphorus concentration on cu, Zn, Fe and Mn utilization by wheat. Can J Soil Sci 54:357-367

Ritz K, Black HIJ, Campbell CD, Harris JA, Wood C (2009) Selecting biological indicators for monitoring soils: A framework for balancing scientific and technical opinion to assist policy development. Ecol Indic 9:1212-1221. https://doi. org/10.1016/j.ecolind.2009.02.009

Rousk J, Bååth E, Brookes PC, Lauber CL, Lozupone C, Caporaso JG, Knight R, Fierer N (2010) Soil bacterial and fungal communities across a $\mathrm{pH}$ gradient in an arable soil. ISME J 4:1340-1351. https://doi.org/10.1038/ismej.2010.58

Rowell DL (1994) Soil science: methods \& applications. Longman Scientific \& Technical. https://doi.org/10.1111 /j.1475-2743.1985.tb00651.x

Rowell DL, Wild A (1984) Causes of soil acidification: a summary. Soil Use Manag 1:32-33

Sherlock E (2012) Key to the earthworms of Britain and Ireland. Field Studies Council

Singh S, Singh J, Vig AP (2016) Effect of abiotic factors on the distribution of earthworms in different land use patterns. $\mathrm{J}$ Basic Appl Zool 74:41-50. https://doi.org/10.1016/j. jobaz.2016.06.001
Sizmur T, Tilston EL, Charnock J, Palumbo-Roe B, Watts MJ, Hodson ME (2011) Impacts of epigeic, anecic and endogeic earthworms on metal and metalloid mobility and availability. J Environ Monit 13:266-273. https://doi.org/10.1039/c0 em00519c

Springett JA, Syers JK (1984) Effect of pH and calcium content of soil on earthworm cast production in the laboratory. Soil Biol Biochem 16:185-189. https://doi.org/10.1016/0038-0717(84 )90110-X

Stork NE, Eggleton P (1992) Invertebrates as determinants and indicators of soil quality. Am J Altern Agric 7:38-47. https://doi.org/10.1017/S0889189300004446

Sullivan, T., Gadd, G.M., 2019. Metal bioavailability and the soil microbiome. In: Advances in agronomy (pp. 79-120). Elsevier Inc. https://doi.org/10.1016/bs.agron.2019.01.004

Tian D, Niu S (2015) A global analysis of soil acidification caused by nitrogen addition. Environ Res Lett 10(2015):024019. https://oi.org/10.1088/1748-9326/10/2/024019

Tibbett M, Diaz A (2005) Are sulfurous soil amendments (S0, $\mathrm{Fe}(\mathrm{II}) \mathrm{SO} 4, \mathrm{Fe}(\mathrm{III}) \mathrm{SO} 4$ ) an effective tool in the restoration of heathland and acidic grassland after four decades of rock phosphate fertilization ? Restor Ecol 13:83-91

Tibbett M, Gil-martínez M, Fraser T, Green I, Duddigan S, De Oliveira V, Raulund-Rasmussen K, Sizmur T, Diaz A (2019) Long-term acidification of $\mathrm{pH}$ neutral grasslands affects soil biodiversity, fertility and function in a heathland restoration. Catena 180:401-415. https://doi.org/10.1016/j. catena.2019.03.013

Tibbett M, Fraser TD, Duddigan S (2020) Identifying potential threats to soil biodiversity. PeerJ 8:1-29. https://doi. org/10.7717/peerj. 9271

Turbé A, De Toni A, Benito P, Lavelle P, Ruiz N, van der Putten WH, Labouze E, Mudgal S (2010) Soil biodiversity: functions, threats and tools for policy makers. Bio Intelligance Serviece, IRD, and NIOO, Report for European Commission. https://doi.org/10.2779/14571

van den Hoogen J, Geisen S, Routh D, Ferris H, Traunspurger W, Wardle DA, De Goede RGM, Adams BJ, Ahmad W, Andriuzzi WS, Bardgett RD, Bonkowski M, CamposHerrera R, Cares J e, Caruso T, de Brito Caixeta L, Chen X, Costa SR, Creamer R, Mauro da Cunha Castro J, Dam M, Djigal D, Escuer M, Griffiths BS, Gutiérrez C, Hohberg K, Kalinkina D, Kardol P, Kergunteuil A, Korthals G, Krashevska V, Kudrin AA, Li Q, Liang W, Magilton M, Marais M, Martín JAR, Matveeva E, Mayad EH, Mulder C, Mullin P, Neilson R, Nguyen TAD, Nielsen UN, Okada H, Rius J, Emilio P, Pan K, Peneva V, Pellissier L, da Silva CPJ, Pitteloud A, Powers TO, Powers K, Quist CW, Rasmann S, Moreno SS, Scheu S, Setälä H, Sushchuk A, Tiunov AV, Trap J, van der Putten $\mathrm{W}$, Vestergård $\mathrm{M}$, Villenave $\mathrm{C}$, Waeyenberge L, Wall DH, Wilschut R, Wright DG, Yang J, Crowther TW (2019) Soil nematode abundance and functional group composition at a global scale. Nature 572:197198. https://doi.org/10.1038/s41586-019-1418-6

van der Bij AU, Weijters MJ, Bobbink R, Harris JA, Pawlett M, Ritz K (2018) Facilitating ecosystem assembly : plant-soil 
interactions as a restoration tool. Biol Conserv 220:272-279. https://doi.org/10.1016/j.biocon.2018.02.010

Xu D, Carswell A, Zhu Q, Zhang F, de Vries W (2020) Modelling long-term impacts of fertilization and liming on soil acidification at Rothamsted experimental station. Sci Total Environ 713:1-12. https://doi.org/10.1016/j.scitotenv.2019.136249

Yeates GW (2003) Nematodes as soil indicators: functional and biodiversity aspects. Biol Fertil Soils 37:199-210

Yeates GW, Bongers T, De Goede RGMC, Freckman DW, Georgieva SS (1993) Feeding habits in soil nematode families and genera-an outline for soil ecologists. J Nematol 25:315-331

Zhang Y, He X, Liang H, Zhao J, Zhang Y, Xu C, Shi X (2016) Long-term tobacco plantation induces soil acidification and soil base cation loss. Environ Sci Pollut Res 23:5442-5450. https://doi.org/10.1007/s11356-015-5673-2

Publisher's note Springer Nature remains neutral with regard to jurisdictional claims in published maps and institutional affiliations. 